The Journal of International Lingual, Social and Educational Sciences Year: 2019, Volume: 5, Number: 1

DOI:10.34137/jilses.578533

Geliș Tarihi: 16.06.2019

Received: 16.06.2019

Kabul Tarihi: 10.07.2019

Accepted: 10.07.2019

Makale Türü: Araştırma Makalesi

Research Type: Research Article

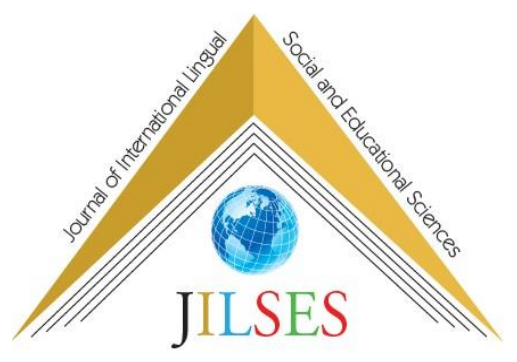

\title{
21. Yüzyıl Yeterlilikleri Ölçeği’nin Geliştirilmesi: Geçerlik ve Güvenirlik Çalışması
}

\section{Ercan Yılmaz ${ }^{1}$ Meryem Alkış ${ }^{2}$}

$\ddot{O}_{z e t}$

Bu araştırmanın amacı, üniversite öğrencilerinin 21. Yüzyıl Yeterliliklerini ölçebilmek amacıyla geçerli ve güvenilir bir ölçme aracı geliştirmektir. 21. Yüzyıl Yeterlilik Ölçeği; Bilgi, Beceri, Karakter ve Metaöğrenme isimli 4 alt ölçeklerle ve her bir alt ölçek diğer ölçeklerden bă̆ımsız bir şekilde kullanılabilecek şekilde yapılandırılmıștır. Yapılan analizler sonucunda 21. Yüzyıl Yeterlilik Ölçeğinin Bilgi alt ölçeğiyle ilgili maddeler (Girişimcilik, Kişisel Finans, Sosyal Sistem, TeknolojiMühendislik, Biyoenerji, Medya ve Să̆lık) yedi faktör altında toplanmıştır. Tüm alt ölçeklere ilişkin maddelerin oluştuğu doğrulayıcı faktör analizinin uyum belirteçleri ile belirlenmiş modeller kuramsal olarak ve istatiksel açıdan uygun bulunmuştur. Sonuç olarak üniversite ögrencilerinin 21. Yüzyll Yeterliliklerini ölçmek amacıyla geliştirilen ölçeklerin geçerli ve güvenilir olduğu ve bu ölçeklerin yeterli düzeyde psikometrik özelliklere sahip olduğu bulunmuştur.

Anahtar Sözcükler: 21. Yüzyll Yeterlilikleri, Bilgi, Beceri Karakter, Metaögrenme, Ölçek Geliştirme

\section{Develop a valid and reliable measurement tool to measure the 21st Century Qualifications}

\begin{abstract}
The aim of this research is to develop a valid and reliable measurement tool to measure the 21st Century Qualifications of university students and older. 21st Century Proficiency Scale; It consists of 4 subscales: Knowledge, Skills, Character and Meta-learning.Each subscale is structured so that it can be used independently of the other scales. The models determined with the fit markers of the confirmatory factor analysis in which the items related to all subscales were found to be theoretically and statistically appropriate. As a result, it was shown that the scales developed to measure the 21st Century Qualifications of university students and over are valid and reliable and have sufficient psychometric properties.
\end{abstract}

Key Words: 21st Century qualifications, Knowledge, Skill, Character, MetaLearning, Scale Development.

\footnotetext{
${ }^{1}$ Prof. Dr., Necmettin Erbakan Üniversitesi, ercanyilmaz70@ gmail.com

${ }^{2}$ Yüksek Lisans Öğr., Necmettin Erbakan, alkismeryem@gmail.com, http://orcid.org/0000-0002-4383-4473
} 


\section{Giriş}

21. yüzyılla birlikte hayatımıza giren kavramlardan en önemlisi değişim olmuştur. Toplumlarda ve yaşamın her yerinde bu değişimi görmek mümkündür. Dünya Ekonomik Forumu (WEF, 2016) hazırlamış olduğu forumda dördüncü sanayi devrimi olarak nitelendirdiği raporunda bu değişimin olduğunu vurgulamış ve bunları robotik, yapay zekalar, yazılımlar ve genetik gibi pek çok farklı alanın 21. yüzyılla birlikte iç içe geçmiş, birbirini destekleyen ve geliştiren bir yapı haline geldiğini vurgulamıştır. Ayrıca teknolojinin ve bilimin böylesine hızlı ilerlediği dünyada, bireylerin daha önceden edinmiş oldukları beceriler ile yaşamlarını sürdürmeleri mümkün olsa da, zor bir hal adlığı yadsınamaz gerçekliğinden bahsedilmiştir. Kulthau'nun (2015) ilk defa dile getirdiği ve günümüz bilim insanlarının da desteklediği 21. yüzyıl öğrenenlerinin eski metot ve yöntemlerin yanı sıra, yeni oluşturulmuş öğrenme ve öğretme metotları kullanılması gerekliliği ortaya çıkmaktadır. Değişim ve dönüşümün hızlı bir şekilde yaşandığı 21. yüzyılda toplumlar her alanda gelişmelere şahit olmaktadırlar (Güneş, 2017). 21. yüzyıl bilim ve teknolojinin hızla ilerlediği bunun yanı sıra kültürel yaşantıların ve eğitim camiasında da pek çok yeniliklerin ve gelişimin ortaya çıktı̆̆ bir dönemin başlangıç noktası haline gelmiştir. Özellikle eğitimin önemini bilen ve bireyin gelişimine önem ve değer veren teorilerin ortaya çıktığı bu çağda, en fazla üzerinde durulan konu da şüphesiz eğitim olmuştur. Çünkü sosyal toplumda eğitimin hedefi, yeni nesillerin sağlıklı ve donanımlı yetiştirmek ve onları geleceğe hazırlamak en önemli amaç olarak belirlenmiştir (Altunbay, 2015).

İnsanoğlu var oluş sürecinden başlayıp, yaşam sonuna kadar durmaksızın öğrenir. Bu öğrenme yaşam boyu; örgün, yaygın ya da bireyin günlük hayatta kendini geliştirerek sağladığı eğitim ve öğrenme faaliyetleri olarak aralıksız devam eder. İnsanın var olmasıyla başlayan eğitim de; bireyleri, yaşadığı toplumu ve dünyayı tamamen ya da dolambaçlı biçimde etkiler. İnsan geçmişteki yaşanmışlıklarıyla birlikte gelecek için planlar yapar. Teknolojinin ilerlemesiyle birlikte bilgi erişimi hızının artması, eğitim alanlarında da bu bilgi teknolojisi kazanımını sağlaması önemlilik arz etmektedir. Bu kazanım sadece bireylerin değil, tüm kurum ve kuruluşların, medeniyetlerin ve hatta ülkelerin geleceğe dair planlama yapma mecburiyetini ortaya çıkarmıştır. Be sebeple eğitim camiası eğitim alanında farklı öğrenme, eğitim becerileri, farklı metotlar ve yöntemler geliştirme gayretindedirler. Eğitim camiasında öne çıkan bu yeni yaklaşımların, eğitim yeterlilikleri ile ilgili 21. yüzyıl beklentileri olduğu inkar edilemez bir hakikattir (Gelen, 2017).

21. yüzyıldaki öğrenci özellikleri, etkili ve kaliteli bir öğrenim görmelerinin yanı sıra, mesleki yaşamlarında da başarı elde edebilmesi için büyük önem taşımaktadır. Teknolojinin gelişmesiyle birlikte, sürekli yeniliklere şahit olduğumuz iş hayatında da, bireylerin sahip olduğu becerilerin geliştirilmesi, söz konusu değişimle birlikte kendini yenileyen ve 21 yüzyıl beklentilerini karşılayabilen, iletişimi kuvvetli, karşılaştığı problemlere çözüm üretebilen aynı zamanda işbirlikçi becerilerine sahip günümüz rekabet piyasasında yer edinebilen nitelikli insan gücü yetiştirilme zorunluluğu doğmaktadır. Bireylere istenilen bu nitelikleri kazandırmak ve hayata hazırlamak konusunda, yükseköğretim kurumlarının bireyin yetiştirilmesinde ve 21. yüzyılın öğrenci özellikleri farkındalıklarının oluşturulmasında üzerine düşen görev ve sorumluluklar tahmin edilenden daha fazladır (Günüç ve diğerleri, 2013).

21. Yüzyıl becerilerinin genel görmüş ortak bir tanımı olmamakla birlikte pek çok farklı kurum ve kuruluş tarafında bu becerilerin farklı sınıflandırmaları yapılmışı̧ı (Çolak, 2018). Trilling ve Fadel (2009), 21. Yüzyıl becerilerinin öğrenen beceriler olarak üç ana başlığa ayırmış bunlar "öğrenme ve yenilik becerileri", "dijital okuryazarlık becerileri" ve "kariyer ve yaşam becerileri" olarak sınıflamış ve her başlığın altında farklı sayılarda alt başlıklarla incelemiştir (Akt. Göksun ve Kurt, 2017). Ledward ve Hirata (2011) göre, 21. yüzy1l becerileri; öğrenme, bilgi, bilim, bilimin harmanlaması, alanındaki ihtisası ve gündelik hayatında ve çalışma ortamında başarıyı elde edebilmek için gerekli beceriler olarak tanımlamıştır. Bahsi geçen bu beceriler geçmiş yıllarda da önemli olarak görülen dayanışma halinde işbirlikçi olma, iletişim kurabilme ve eleştirel düşünme vb pek çok becerilere ilaveten teknolojinin gelişmesi ve bilgi teknolojisi alanında yeniliklerin takip edilmesi, teknoloji okuryazarlı̆̆ benzeri yeni becerileri de içine almaktadır (Ekici ve diğerleri, 2017).

Önceki yüzy1llarda kesin bilgi kıymetli ve kabul edilebilir görülürken günümüzde bilgi sahibi olmak kafi gelmemektedir. 21. yüzyıl bireylerinde hem eğitim, hem de iş hayatlarında başarıyı elde edebilmeleri ve artan talepleri karşılayabilmeleri için geçmiş yüzyılın kesin bilgiye sahip diplomalı bireylerin aksine, çeşitli becerilere hakim olma zorunlulukları doğmaktadır. Yalnızca işini yerine getiren değil aynı zamanda üretken, sorunları çözen, yaratıc1, kendi kendini yönlendirebilen, kabiliyetli, iletişimi ve sosyal becerileri kuvvetli kişiler aranmaktadır (Eryılmaz ve Uluyol, 2015). Eğitimde de sözünü ettiğimiz bu becerileri tüm bireylere kazandırmaya çalışılması fikri gün geçtikçe artarak yaygınlaşmaktadır. "Tüm bireylere" vurgusu bu anlamda oldukça mühimdir. Çünkü belli bir kesimde yer alan kısıtlı sayıda öğrenciyi kapsayan değil, bütün öğrencileri içine aldığ 1 için, hayati ve büyük anlam içermektedir. Yeni yeni gündeme gelen bu durumun öğretim programları içerisinde 21. yüzyıl becerilerinin daha detaylı ve sistematik boyutta yer alması zorunluluğu doğmaktadır (Ekici ve diğerleri, 2017). Bireylere 21. yüzyıl becerileri olarak ifade edilen becerilerin kazandırılması amacıyla eğitim programlarına entegre edilmesi önem taşıdığı düşünülmektedir. Ayrıca bir takım becerilerden söz ediyorsak, elbette sözünü ettiğimiz becerilerin 
ölçebilmenin önemi ortaya çıkmaktadır. Bu amaçla 21. yüzyıl becerileri ve kişilere kazandırılması amaçlanan standartların oluşturulması ve belirlenen bu standartların uygun olarak ölçülmesi için ölçeklerin geliştirilmesi gerekmektedir (Eryılmaz ve Uluyol, 2015). Unutulmamalıdır ki 21. yüzyıl becerilerinin öneminin artması sonucu, bu becerilerin temelden en baştan tanımlanması, kapsamının ayrıntılı olarak incelenmesi, bu becerilerin neler olduğu ve kabul gören ortak bir sınıflanmanın yapılması önem arz etmektedir (Yalçın, 2018).

Bu araştırmada üniversite öğrencilerinin 21. Yüzyıl Yeterliliklerini ölçmek amacıyla geçerli ve güvenilir bir ölçme aracı geliştirmek amaçlanmıştır.

\section{Yöntem}

\section{Çalıșma Grubu}

Araştırmanın katılımcıları 2018-2019 eğitim-öğretim yılında büyükşehirlerden birinde yer alan 3 farklı üniversitede öğrenim görmekte olan 560 üniversite öğrencisinden oluşmaktadır. Araştırmanın yapılacağ üniversiteler araştırmanın amacına uygunluğu da göz önüne alınarak rasgele seçilmiştir. Araştırmanın amacı doğrultusunda üniversite öğrencileriyle çalışma yürütülmüştür. Çalışma yapılacak üniversitelerde belirlenmesinde araştırmacılar, üniversite yönetimleri ve öğretim elemanları açısından uygunluk, kolay ulaşılabilirlik, katılımda gönüllülük, yeterli katılımcı sayısının elde edilebilmesi gibi durumlar göz önüne alınmıştır. Katılımcılar basit seçkisiz örnekleme yöntemiyle seçilmiştir. Bu yöntem temsil özelliği yüksek bir örneklem elde edilebilmesi ve yapılacak istatistiksel yorumların genellenebilmesi bakımından etkili bir yöntemdir (Gay, Mills \& Airasian, 2009). Katılımcıların 204'ü (\%55) erkek ve 167'si (\%45) kadın öğrencidir. Katılımcıların \%42'si sözel alan, \%45'i sayısal alan ve \%13'ü yetenek alanlarında; \%21'i özel üniversite \%79'u kamu üniversitesinde öğrenim görmektedirler.

\section{Taslak Ölçeğin Geliştirilmesi}

Araştırmada kullanılmak üzere gerekli verileri toplamak için 21. Yüzyıl Yeterlilikleri Ölçeği taslağı ve kişisel bilgi formu kullanılmıştır. 21. Yüzyıl Yeterlilikleri Ölçeğinin taslak halinin hazırlanmasında madde havuzunun oluşturulması, uzman görüşlerinin alınması, pilot uygulama, geçerlik ve güvenirlik belirleme gibi ölçek geliştirme aşamaları izlenmiştir (Şeker ve Gençdoğan, 2014; Tavşancıl, 2005). 21. Yüzyıl Yeterlilikleri Ölçeğinin taslak maddelerinin oluşturulmasında ilgili literatürdeki kuramsal yapıdan ve yapılmış araştırma sonuçlarından faydalanılmıştır (Akpınar ve Altun, 2014; Aksoy, 2006; Arslan ve Durukan, 2015; Aybek, ve diğerleri, 2015; Barmaki, 2015; Baş, 2012; Biçer, 2008; Bozkurt, 2014; Boztepe, 2017; Cabı, 2016; Doğan, 2013; Dönmez ve Kaya, 2016; Ekinci, 2015; Ersanlı ve Balc1, 1998; Göncüoğlu, 2010; Gülay, 2013; Güven ve Kürüm, 2006; Kasalak, 2017; Kenar, 2012; Kılıç ve Kurtuluş, 2009; Korkut Owen ve Bugay, 2014; Korkut ve Akkoyunlu, 2008; Korkut, 1996; Narin, 2009; Özsoy, 2008; Pamukcu, 2013; Sarı̈öz, 2014; Savaş, 2011; Seferoglu ve Akbıyık, 2006; Sungur, 2011; Şahin, 2010; Şen, 2009; Tekin Bender, 2006; Tosun, 2016; Ünlü, 2008; Yanık, 2007; Y1ldırım ve Selvi, 2015 ve Y1lmaz ve Sünbül, 2009; Yüksel, 2014).

21. Yüzyıl Yeterlilikleri boyutlarıyla ele alınıp çalışmaya uygun bir şekilde maddeler hazırlanmıştır. Taslak ölçek maddeleri ile üniversite öğrencilerin kendi algısına dayalı 21. yüzyıl yeterliliklerine sahip olmalarıyla ilgili düzeylerinin belirlenmesi amaçlanmıştır. Ayrıca nihai 21. Yüzyıl Yeterlilikleri Ölçeğinde aday maddeler dört alt ölçekte kümelendirilmiştir. Bu alt ölçekler; "Bilgi", "Beceri”, "Karakter" ve "Metaöğrenme"'dir. İlgili alt ölçeklere karar vermeden önce, ölçeklerde uygun maddeler olmasına dikkat edilmiştir. İlgili ölçeklere son hali verilmeden önce konuda uzman kişilerin (15 alanında uzman) görüşlerine başvurulmuştur. Ölçek ile ilgili alınan görüşler doğrultusunda gerekli değişiklikler ve düzeltmeler yapılmıştır. İlgili uzmanlar, maddelere ilişkin içerik, yapı, uygulanabilirlik ve anlam açılarından görüşlerini bildirmişlerdir. Bazı uzmanlara göre ölçeğin çok fazla sayıda madde içermemesi ve bu yüzden bazı tekrar eden maddelerin silinmesi gerektiği bildirilmiştir Ayrıca uzman görüşleri doğrultusunda dil, anlatım ve ifade açısından maddelerin yazımında bazı küçük değişiklikler yapılmıştır. Hedeflenen teorik yapıyı ölçmede bu madde sayısının yeterli olduğu kabul edilmiştir. Ayrıca ölçekteki bazı maddelerin tam olarak anlaşılmadığı ve daha basit cümleler ile ifade edilmesi gerektiği bildirilmiştir. Uzmanlardan alınan dönütler doğrultusunda bazı maddeler silinmiş, geriye kalan maddelerde ise yazım, biçim, dil ve anlatım bakımından değişiklik ve düzeltmeler yapılmıştır. Sonuçta uzman görüşleri doğrultusunda ve gerekli düzenlemelerle 110 madde olarak hazırlanan taslak ölçek 87 maddeye düşürülmüştür.

Son olarak 21. Yüzyıl Yeterlilikleri Ölçeğinin taslak formu 87 madde olarak, 5 dereceli likert tipinde hazırlanmıştır. 21. Yüzyıl Yeterlilikleri Ölçeğinin maddeleri "kesinlikle katılıyorum (5 puan)", "katıllyorum (4 puan)", "kararsızım (3 puan)", "katılmıyorum (2 puan)" ve "kesinlikle katılmıyorum (1 puan)" seçeneklerini içermektedir. 21. Yüzyıl Yeterlilikleri Ölçeğindeki maddeler 5-4-3-2-1 şeklinde puanlanmıştır. Ölçeklerden alınan yüksek puanlar ilgili boyutundaki becerisinin güçlü, düşük puanlar ise zayıf beceriye sahip oldukların göstermektedir. Araştırmacı tarafindan geliştirilen taslak ölçek katılımcılara bir ders saatinde uygulanmıştır. 
Uygulama sürecinde öğrencilere kişisel bilgi formu ve 21. Yüzyıl Yeterlilikleri Ölçeğinin nasıl uygulanacağı hakkında bilgiler verilmiştir ve öğrenciler tarafından anlaşılmayan hususlar hakkında açıklamalar yapılmışıtır.

\section{Verilerin Analizi}

Taslak ölçek maddelerinin analiz sürecinde; taslak ölçeğe yönelik madde analizleri, yapı geçerliğinin belirlenmesi amacıyla açımlayıcı ve doğrulayıcı faktör analizleri yapılmıştır. Doğan, Soysal ve Karaman (2017) çalışmalarında aynı örneklem ile yapılan faktör analizleri sonuçları ile açımlayıcı ve doğrulayıcı faktör analizlerinin bir örneklemin farklı yarılarına uygulandığı durumlarda elde edilen sonuçların benzer olduklarını belirtmişlerdir. Bu doğrultuda katılımcılara ulaşma zorluğundan dolayı açımlayıcı ve doğrulayıcı faktör analizleri aynı örneklemden elde edilen veriler ile gerçekleştirilmiştir. Taslak ölçek maddelerinin ölçeklerle ilgili olup olmadığının belirlenmesi için madde-toplam puan korelasyon değerlerine bakılmıştır. Ölçeklerin güvenirliğini belirlemek için Cronbach alfa iç tutarlılık katsayısı yönetimi kullanılmıştır. Alt ve üst grup farkı için t değeri, maddelerden alınan puanlarının ortalaması ve standart sapması hesaplanmıştır. Alt Ölçeklerin faktörleri arasındaki korelasyon katsayıları bulunmuştur.

\section{Bulgular}

Aşağıda 21. Yüzyıl Yeterlilikleri Ölçeği oluşturan dört alt ölçeğin geçerlilik ve güvenirlik kestirim süreçleri ayrı ayrı verilmiştir. Dört alt ölçeğin ölçtüğü yapı birbirinden farklı olduğu için ölçekler ayrı ayrı kullanılabilir.

\section{Yüzyil Yeterlilikleri Bilgi Alt Ölçeği}

\section{Madde Analizi}

Taslak ölçek maddelerinin 21. Yüzyıl Yeterlilikleri Bilgi Alt Ölçeği ile ilgili olup olmadığının belirlenmesi amacıyla öncelikle madde analizi yapılmıştır. Bilgi alt ölçeğinin madde-toplam puan korelasyonlarına bakıldığında ilgili değerlerin 0,266 ile 0,579 arasında değiştiği görülmektedir. Bu değerlerin çoğunun 0.30 'un üstünde olduğu görülmüştür. Genel olarak madde-toplam puan korelasyonunun 0.30 üzerindeki maddelerin uygun olduğu fakat 0.20-0.30 arasındaki değerlerin uygun görülmesi durumunda teste alınabileceği belirtilmektedir (Büyüköztürk, 2015). Bu sebepten dolayı ölçekteki maddelerin analize uygun olduğu kabul edilmiştir.

\section{Yapı Geçerliği}

\section{Yüzyıl Yeterlilikleri Bilgi Alt Ölçeği’nin Açımlayıcı Faktör Analizi (AFA)}

21. Yüzyıl Yeterlilikleri Beceri Ölçeğinin yapı geçerliğini belirlemek amacıyla faktör analizine uygunluğun incelenmesi, faktör analizlerinin yapılması, faktörlerin belirlenmesi ve faktörlerin isimlendirilmesi aşamaları izlenmiştir (Kalayc1, 2014).

İlk etapta katılımcı sayısının gerekli verilerin toplanabilmesi açısından yeterli olmasına özen gösterilmiştir. Kline’ a (1994) göre faktör analizi yapılacak çalışmalarda katılımcı sayısının en az 100 olması koşulu ile katılımcı sayısının değişken sayısına oranının en az 2 olması gerekir. Bu açıklamalara dayalı bir şekilde katılımcı sayısının yeterli olduğu kabul edilmiştir.

21. Yüzyıl Yeterlilikleri Ölçeğinin Bilgi Alt Ölçeği için toplanan verilerin faktör analizi için uygunluğunun tespiti için Kaiser-Meyer-Olkin (KMO) katsayısına, Bartlett küresellik testi sonucuna ve veri matrisinin köşegen değerlerine bakılmıştır. KMO katsayısının 0.60 üzerinde olması, Bartlett testi sonuçlarının anlamlı çıkması (Büyüköztürk, 2015) ve anti-imaj matrisinin esas köşegen elemanlarının 0.50 değerinden büyük olması maddelerin faktör analizi için uygun olduğu anlamına gelmektedir (Pett, Lackey \& Sullivan, 2003). Toplanan veriler için KMO katsayısı 0.853 olarak hesaplanmıştır. Bunun yanı sıra Bartlett testi Ki-kare değeri istatistiksel olarak anlamlı $(\mathrm{X} 2=7051,715 ; \mathrm{p}<0.01)$ çıkmıştır. Anti-imaj matrisindeki köşegen değerlerinin tamamı 0.50 değerinden büyüktür. Bu sonuçlar. 21. Yüzyıl Yeterlilikleri Bilgi Alt Ölçeği için toplanan verilerin faktör analizi için gerekli şartları sağladığı kabul edilmiştir.

Açımlayıcı faktör analizlerinde (AFA) faktör yüklerinin hesaplanmasında temel bileşenler analizi (Principal Component) metodu, döndürme tekniği olarak varimax kullanılmıştır. Varimax yöntemi ile basit yapıya ve anlamlı faktörlere ulaşmada, faktör yükleri matrisinin sütunlarına öncelik verilir. Bu yöntemle daha az değişkenle faktör varyanslarının maksimum olması sağlanacak şekilde döndürme yapılır (Tavşancıl, 2005). Faktör analizinde öz değeri 1'den büyük olan faktörler önemli faktörlerdir. Bir maddenin bir faktörde yer alabilmesi için faktör yükünün en az 0.45 olması iyi bir ölçüdür. Gerekli durumlarda bu değer 0.30'a kadar indirilebilir (Büyüköztürk, 2015). Bu doğrultuda faktörlerin belirlenmesinde öz değerlerinin 1'den büyük olması ve maddelerin bir faktörde yer alabilmesi için faktör yüklerinin en az 0.40 olması durumu gözetilmiştir. İlk AFA sonucunda maddelerin 7 faktöre dağılldığı scree plot grafiğine göre asıl faktör sayısının 7 ya da 8 olabileceği görülmüştür. 


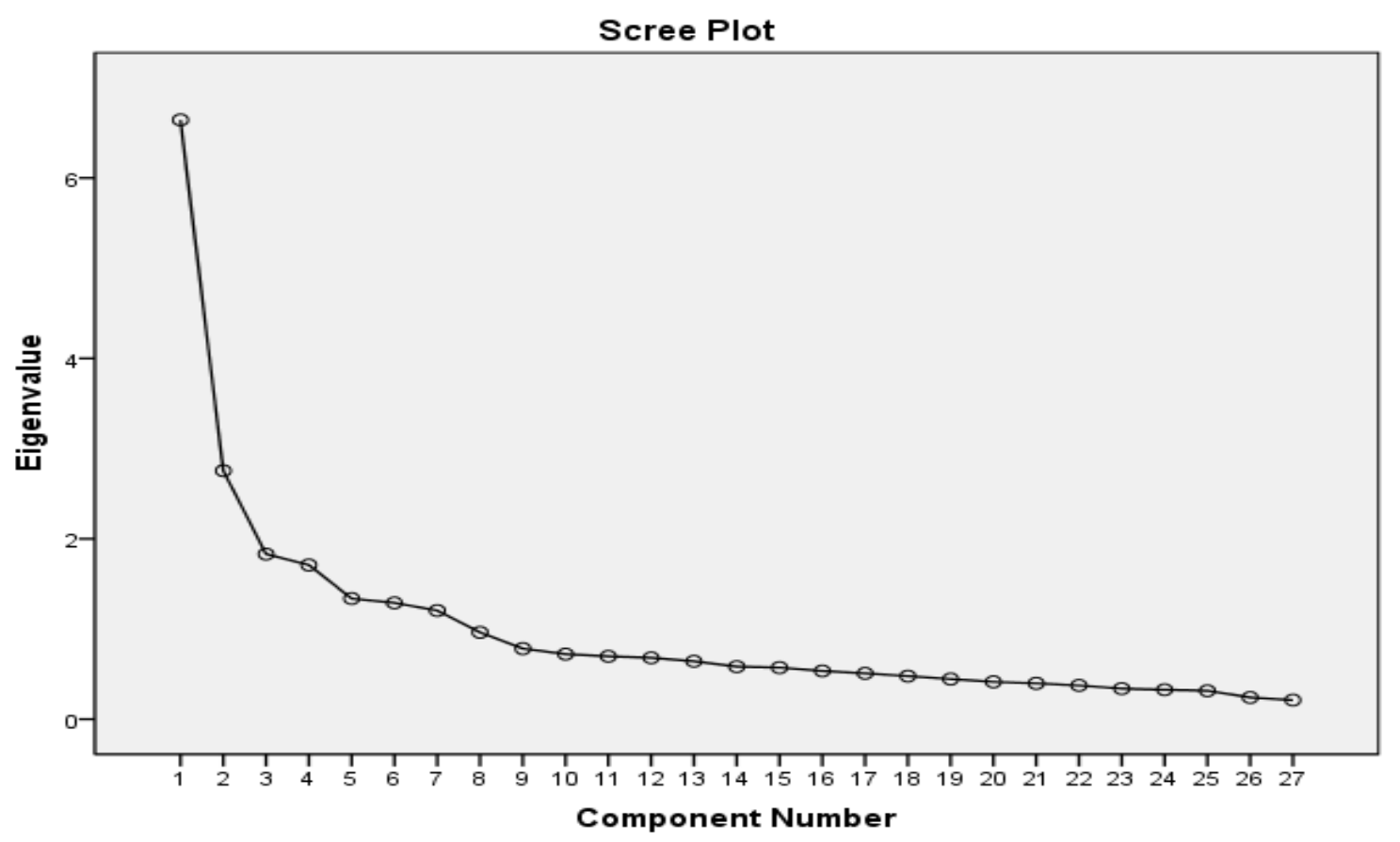

\section{Şekil 1. 21. Yüzyll Yeterlilikleri Bilgi Alt Ölçeği’nin Yamaç Birikinti Grafiği}

Scree-plot (yamaç birikinti grafiği) yöntemi, AFA'da faktör sayısına karar vermede kullanılır. Grafikte Y ekseni öz değerleri, $X$ ekseni ise bileşen sayısını göstermektedir. Bu yönteme göre grafikte eğimin azaldığı kırılma noktasından sonraki faktörlerin varyansa katkıları ihmal edilebilecek büyüklüktedir. Şekil 1'de eğimin hemen hemen kaybolduğu kırılma noktasında X ekseni bileşen sayısı yedi olarak görülmektedir. Bu nedenle önemli faktör sayısının en az yedi olabileceğine karar verilmiştir. Bu araştırmada 1'den büyük öz değerlere sahip faktörler ve kuramsal temeller de göz önüne alındığında yedi faktörlü bir yapının olabileceği kabul edilmiştir. Taslak formundaki 29 maddeden faktör yükü 0.40 'ın altında olan ya da birden fazla faktöre yüklenen binişik 2 maddenin çıkarılması yoluna gidilmiştir. Bu doğrultuda birden fazla faktöre yüklenen maddeler sırasıyla çıkarılıp faktör yükleri tekrar hesaplanmıştır. Sonuçta 7 alt faktörlü ve açıklanan varyans oranı $\% 62,117$ olan yapı elde edilmiştir. AFA sonucu elde edilen faktörler ve maddelerin faktör yükleri Tablo 1'de görülmektedir.

Açımlayıcı faktör analizinde elde edilen faktör yüklerinin .505 ile .820 arasında olduğu görülmektedir. Bu da elde edilen faktör yüklerinin belirtilen alt sınırların üstünde olduğunu göstermektedir. Buna göre faktörlere yüklenen maddeler istenen yapıyı uygun bir şekilde ölçmektedir (Büyüköztürk, 2015). Elde edilen faktörler içerdiği maddelere bakılarak isimlendirilmiştir. Bu doğrultuda 8 maddeden $(\mathrm{m} 3, \mathrm{~m} 4, \mathrm{~m} 5, \mathrm{~m} 6, \mathrm{~m} 7, \mathrm{~m} 8, \mathrm{~m} 9$ ve $\mathrm{m} 10)$ oluşan birinci faktöre "Girişimcilik", 5 maddeden ( $\mathrm{m} 11, \mathrm{~m} 12, \mathrm{~m} 13, \mathrm{~m} 14$ ve $\mathrm{m} 15)$ oluşan ikinci faktöre "Kişisel Finans" , 3 maddeden (m25, m26 ve m27) oluşan üçüncü faktöre "Sosyal Sistem", 4 maddeden (m21, m22, m23 ve m24) oluşan dördüncü faktöre "Teknoloji ve Mühendislik", 2 maddeden ( $\mathrm{m} 1 \mathrm{ve} \mathrm{m} 2$ ) oluşan beşinci faktöre "Biyoenerji", 3 maddeden ( $\mathrm{m} 16, \mathrm{~m} 17$ ve m18) oluşan altıncı faktöre "medya" ve 2 madden (m19 ve m20) oluşan yedinci faktöre "Sağllk" denilmiştir. 
Tablo 1. 21. Yüzyıl Yeterlilikleri Bilgi Alt Ölçeği’nin döndürülmüş bileşenler matrisi (varimax)

\begin{tabular}{|c|c|c|c|c|c|c|c|}
\hline & Bileşe & & & & & & \\
\hline & 1 & 2 & 3 & 4 & 5 & 6 & 7 \\
\hline B3 & ,696 & & & & & & \\
\hline B5 & 693 & & & & & & \\
\hline B9 & ,682 & & & & & & \\
\hline B4 & ,613 & & & & & & \\
\hline B7 &, 596 & & & & & & \\
\hline B6 & ,538 & & & & & & \\
\hline B10 &, 536 & & & & & & \\
\hline B8 &, 505 & & & & & & \\
\hline B13 & &, 820 & & & & & \\
\hline B14 & &, 783 & & & & & \\
\hline B15 & &, 731 & & & & & \\
\hline B12 & & ,694 & & & & & \\
\hline B11 & & ,591 & & & & & \\
\hline B26 & & & ,669 & & & & \\
\hline B25 & & &, 656 & & & & \\
\hline B27 & & & ,644 & & & & \\
\hline B23 & & & & ,762 & & & \\
\hline B22 & & & &, 744 & & & \\
\hline B24 & & & & ,729 & & & \\
\hline B21 & & & & ,614 & & & \\
\hline B1 & & & & &, 745 & & \\
\hline B2 & & & & & ,726 & & \\
\hline B17 & & & & & &, 717 & \\
\hline B18 & & & & & & ,669 & \\
\hline B16 & & & & & &, 550 & \\
\hline B20 & & & & & & & ,731 \\
\hline B19 & & & & & & & 664 \\
\hline
\end{tabular}

Açıklanan Varyans Toplam: \% 62,117, Faktör 1: \% 24,608, Faktör 2: \% 10,205, Faktör 3: \%6,780, Faktör 4: 6,332, Faktör 5: 4,953, Faktör 6: 4,778 ve Faktör 7: 4,461 
Tablo 2. 21. Yüzyıl Yeterlilikleri Bilgi Alt Ölçeği’nin faktörleri arasındaki korelasyon katsayıları

\begin{tabular}{|c|c|c|c|c|c|c|c|c|}
\hline & & $\begin{array}{l}\text { Girişimcili } \\
\mathbf{k}\end{array}$ & $\begin{array}{l}\text { Kişisel } \\
\text { Finans } \\
\end{array}$ & Medya & Sağlık & $\begin{array}{l}\text { Teknoloji ve } \\
\text { Mühendislik } \\
\end{array}$ & $\begin{array}{l}\text { Sosyal } \\
\text { Sistem } \\
\end{array}$ & Biyoenerji \\
\hline \multirow[t]{2}{*}{ Girişimcilik } & $\mathrm{r}$ & 1 &, $278^{* *}$ &, $285^{* *}$ &, $244^{* *}$ &, $426^{* *}$ &, $490^{* *}$ &, $288^{* *}$ \\
\hline & $\mathrm{p}$ & &, 000 &, 000 &, 000 &, 000 &, 000 &, 000 \\
\hline \multirow[t]{2}{*}{ Kişisel Finans } & $\mathrm{r}$ &, $278^{* *}$ & 1 &, $128^{*}$ &, $209^{* *}$ &, $185^{* *}$ &, $148^{* *}$ &, $118^{*}$ \\
\hline & $\mathrm{p}$ &, 000 & &, 024 &, 000 &, 001 &, 009 &, 036 \\
\hline \multirow[t]{2}{*}{ Medya } & $\mathrm{r}$ &, $285^{* *}$ &, $128^{*}$ & 1 &, $230^{* *}$ &, $313^{* *}$ &, $281^{* *}$ &, $138^{*}$ \\
\hline & $\mathrm{p}$ &, 000 &, 024 & &, 000 &, 000 &, 000 &, 015 \\
\hline \multirow[t]{2}{*}{ Sağlık } & $\mathrm{r}$ &, $244^{* *}$ &, $209^{* *}$ &, $230^{* * *}$ & 1 &, $168^{* *}$ &, $199^{* *}$ &, 122 \\
\hline & $\mathrm{p}$ &, 000 &, 000 &, 000 & &, 003 &, 000 &, 035 \\
\hline \multirow{2}{*}{$\begin{array}{l}\text { Teknoloji ve } \\
\text { Mühendislik }\end{array}$} & $\mathrm{r}$ &, $426^{* *}$ &, $185^{* *}$ &, $313^{\text {*** }}$ &, $168^{* *}$ & 1 &, $397^{* *}$ &, $329^{* *}$ \\
\hline & $\mathrm{p}$ &, 000 &, 001 &, 000 &, 003 & &, 000 &, 000 \\
\hline \multirow[t]{2}{*}{ Sosyal Sistem } & $\mathrm{r}$ &, $490^{* *}$ &, $148^{* *}$ &, $281^{* * *}$ &, $199^{* *}$ &, $397^{* *}$ & 1 &, $186^{* *}$ \\
\hline & $\mathrm{p}$ &, 000 &, 009 &, 000 &, 000 &, 000 & &, 001 \\
\hline \multirow[t]{2}{*}{ Biyoenerji } & $\mathrm{r}$ &, $288^{* *}$ &, $118^{*}$ &, $138^{*}$ &, 122 &, $329^{* *}$ &, $186^{* *}$ & 1 \\
\hline & $\mathrm{p}$ &, 000 &, 036 &, 015 & ,035 &, 000 & ,001 & \\
\hline
\end{tabular}

Tablo 2 incelendiğinde, ölçeğin alt boyutları arasındaki korelasyonların .122 ile .490 arasında değiştiği ve .05 düzeyinde anlamlı ilişkiye sahip olduğu görülmektedir. Açımlayıcı faktör analizi sonrasında ortaya çıkan modelin, yapı geçerliğini değerlendirmek için doğrulayıcı faktör analizi (DFA) yapılmıştır (Kline, 2011).

\section{Yüzyıl Yeterlilikleri Ölçeği’nin Bilgi Alt Ölçeğinin Doğrulayıcı Faktör Analizi (DFA)}

Doğrulayıcı Faktör Analizi (DFA) ölçek geliştirme çalışmalarında AFA ile birlikte kullanılmaktadır. DFA ile eldeki veriler ile mevcut teorik yapının ne ölçüde örtüştüğü test edilebilmektedir (Schumacker \& Lomax, 2004). AFA sonucu elde edilen 7 faktörlü 27 madde içeren "Bilgi Alt Ölçeği" doğrulayıcı faktör analizine tabi tutulmuştur.

Tablo 3. 21. Yüzyıl Yeterlilikleri Bilgi Alt Ölçeği’nin DFA sonuçlarının uyum indeksi değerleri ve karşılaștırılması

\begin{tabular}{lllllll}
\hline Model & $\boldsymbol{\chi}$ 2/sd & GFI & CFI & IFI & NNFI & RMSEA \\
\hline & $432,755 / 299=1,447$ & 0,906 & 0,952 & 0,953 & 0,901 & 0,038 \\
\hline $\begin{array}{l}\text { Uyum } \\
\text { Yorumu* }\end{array}$ & Mükemmel Uyum & $\begin{array}{l}\text { Mükemmel } \\
\text { Uyum }\end{array}$ & $\begin{array}{l}\text { Mükemmel } \\
\text { Uyum }\end{array}$ & $\begin{array}{l}\text { Mükemmel } \\
\text { Uyum }\end{array}$ & $\begin{array}{l}\text { Kabul } \\
\text { Edilebilir } \\
\text { Uyum }\end{array}$ & $\begin{array}{l}\text { Mükemmel } \\
\text { Uyum }\end{array}$ \\
\hline
\end{tabular}

\footnotetext{
* (Bayram, 2013; Hu \& Bentler, 1999; Schumacker \& Lomax, 2004)
}

DFA sonucunda 7 faktörlü olarak elde edilen ölçeğin uyum indekslerinin genellikle iyi değerler aldığı görülmektedir. Ki kare değerinin serbestlik derecesine oranı, $(\chi 2 /$ sd=1,447) 2’den küçük çıkmıştır. GFI (Goodness of Fit Index), CFI (Comparative Fit Index), IFI (Incremental Fit Index) ve NNFI (Non-Normed Fit Index) uyum indekslerinin 0.95 değerine yakın, RMSEA değerinin 0.05 ten küçük olması modelin verilerle iyi uyum sağladığının göstergesi olarak kabul edilebilir. Bu çalışmadaki ölçek için elde edilen uyum indeksleri öne sürülen model ve eldeki verileri iyi uyum gösterdiğinin kanıtı olarak kabul edilebilir.

Ölçeğin her bir faktöründeki maddelerin bulunduğu faktörü temsil etme düzeyleri için standardize yol diyagramlarına bakılmıştır. 


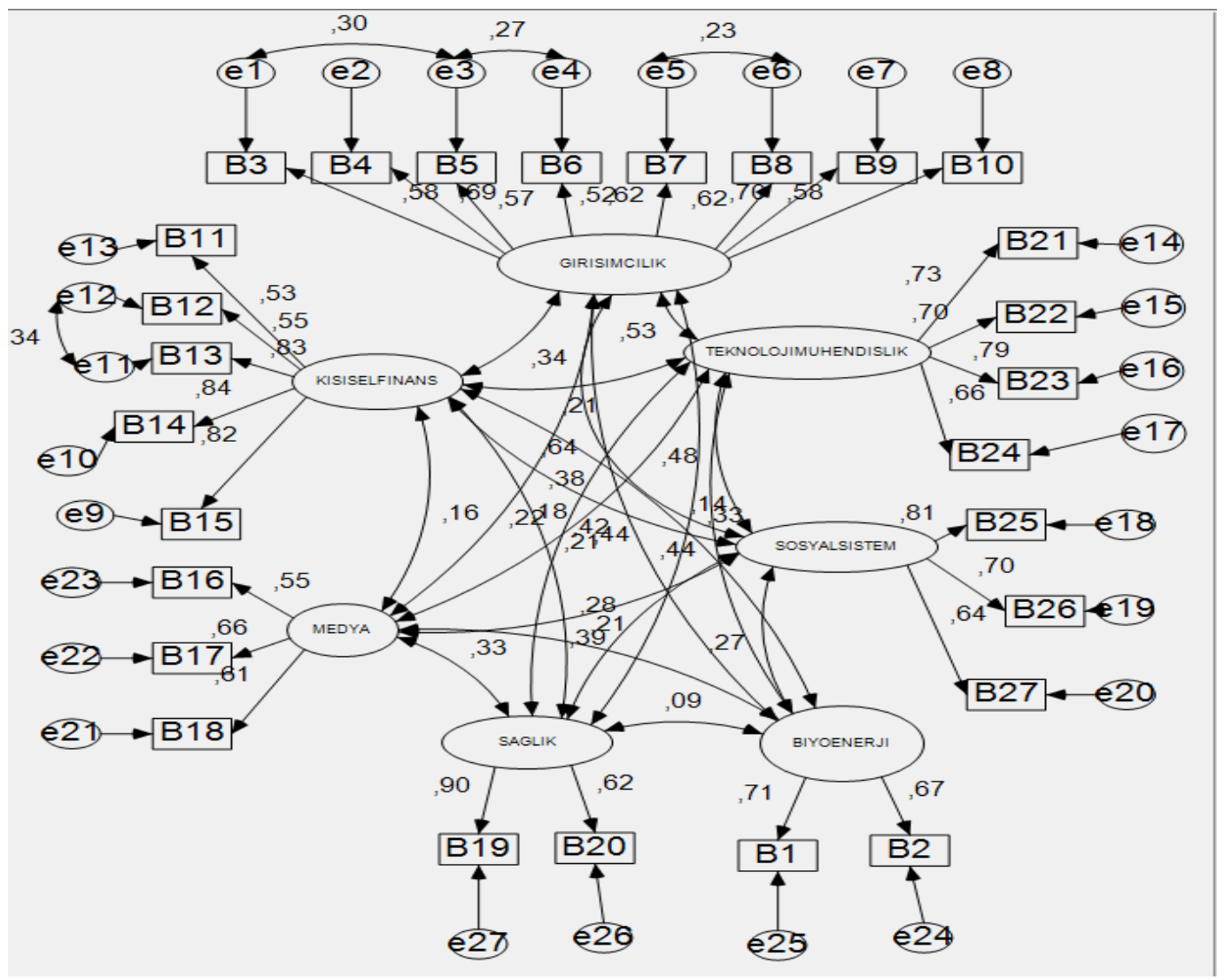

Şekil 2. 21. Yüzyıl Yeterlilikleri Bilgi Alt Ölçeği’nin DFA sonuçları: Standartlaştırılmış Yol Diyagramları

Maddelerin standardize yol katsayıları 0.53 ile 0.90 arasında değişmektedir. Bu değerler maddelerin bulundukları faktörleri iyi bir şekilde temsil ettiğini göstermektedir.

Tablo 4'de ölçeğin maddelerin; madde-toplam puan korelasyon değerleri, faktör yükleri, alt ve üst grup farkı için $\mathrm{t}$ değeri, alınan puanlarının ortalaması ve standart sapması verilmiştir. 
Tablo 4. 21. Yüzyıl Yeterlilikleri Bilgi Alt Ölçeği’nin Ölçek maddelerine ait bazı geçerlik güvenirlik analizi değerleri

\begin{tabular}{|c|c|c|c|c|c|c|c|}
\hline Faktör & $\begin{array}{l}\text { Madde } \\
\text { No }\end{array}$ & $\begin{array}{l}\text { Madde-toplam } \\
\text { puan } \\
\text { korelasyonu }\end{array}$ & $\begin{array}{l}\text { AFA } \\
\text { faktör } \\
\text { yükü }\end{array}$ & $\begin{array}{l}\text { Alt ve üst } \\
\text { grup farkı } \\
\text { için t değeri }\end{array}$ & $\begin{array}{l}\text { Madde } \\
\text { Ortalama }\end{array}$ & $\begin{array}{l}\text { Standart } \\
\text { sapma }\end{array}$ & $\begin{array}{l}\text { Cronbach } \\
\text { alfa iç } \\
\text { tutarlılık } \\
\text { katsayısı } \\
\end{array}$ \\
\hline \multirow[t]{8}{*}{ Girişimcilik } & B3 &, 454 & ,696 & $10,34 * *$ & 3,64 & ,97 & \multirow{8}{*}{0,829} \\
\hline & B5 &, 511 & ,693 & $10,91 * *$ & 4,20 &, 78 & \\
\hline & B9 &, 520 & ,682 & $10,98 * *$ & 4,16 &, 77 & \\
\hline & $\mathrm{B} 4$ &, 579 &, 613 & $12,29 * *$ & 4,34 &, 71 & \\
\hline & $\mathrm{B} 7$ & ,492 & ,596 & $10,49 * *$ & 4,35 &, 61 & \\
\hline & B6 &, 424 &, 538 & $11,36 * *$ & 4,33 &, 70 & \\
\hline & $\mathrm{B} 10$ &, 455 &, 536 & $9,40 * *$ & 3,97 &, 85 & \\
\hline & $\mathrm{B} 8$ & ,495 &, 505 & $10,34 * *$ & 4,36 &, 64 & \\
\hline \multirow{5}{*}{$\begin{array}{l}\text { Kişisel } \\
\text { Finans }\end{array}$} & $\mathrm{B} 13$ &, 401 &, 820 & $9,83 * *$ & 4,29 & ,92 & \multirow{5}{*}{0.841} \\
\hline & $\mathrm{B} 14$ &, 417 &, 783 & $9,53 * *$ & 4,27 &, 81 & \\
\hline & $\mathrm{B} 15$ &, 441 &, 731 & $10,30 * *$ & 4,17 &, 88 & \\
\hline & $\mathrm{B} 12$ &, 267 & ,694 & $6,76 * *$ & 4,23 & 1,01 & \\
\hline & $\mathrm{B} 11$ & ,461 &, 591 & $10,67 * *$ & 4,35 &, 70 & \\
\hline \multirow{3}{*}{$\begin{array}{l}\text { Sosyal } \\
\text { Sistem }\end{array}$} & $\mathrm{B} 26$ &, 441 & ,669 & $10,96 * *$ & 4,31 &, 68 & \multirow{3}{*}{0,759} \\
\hline & $\mathrm{B} 25$ &, 509 &, 656 & $13,40 * *$ & 4,30 & ,64 & \\
\hline & $\mathrm{B} 27$ & ,399 & ,644 & $8,68 * *$ & 4,26 &, 64 & \\
\hline \multirow{4}{*}{$\begin{array}{l}\text { Teknoloji ve } \\
\text { Mühendislik }\end{array}$} & $\mathrm{B} 23$ &, 474 &, 762 & $10,41 * *$ & 4,15 &, 84 & \multirow{4}{*}{0,809} \\
\hline & $\mathrm{B} 22$ &, 470 &, 744 & $10,36 * *$ & 4,26 &, 71 & \\
\hline & B24 &, 418 &, 729 & $8,75 * *$ & 4,27 &, 81 & \\
\hline & $\mathrm{B} 21$ &, 525 & ,614 & $11,67 * *$ & 4,23 &, 74 & \\
\hline \multirow[t]{2}{*}{ Biyoenerji } & $\mathrm{B} 1$ &, 300 &, 745 & $5,18 * *$ & 4,44 &, 68 & \multirow[t]{2}{*}{0,644} \\
\hline & $\mathrm{B} 2$ &, 287 &, 726 & $5,54 * *$ & 4,51 &, 63 & \\
\hline \multirow[t]{3}{*}{ Medya } & B17 & ,266 &, 717 & $6,76 * *$ & 3,45 & 1,10 & \multirow{3}{*}{0.624} \\
\hline & B18 &, 350 & ,669 & $8,38 * *$ & 3,95 & ,92 & \\
\hline & $\mathrm{B} 16$ & ,392 &, 550 & $7,22 * *$ & 4,21 &, 74 & \\
\hline \multirow[t]{2}{*}{ Sağlık } & $\mathrm{B} 20$ &, 277 &, 731 & $6,72 * *$ & 3,54 & 1,05 & \multirow[t]{2}{*}{0,716} \\
\hline & B19 &, 372 & ,664 & $8,89 * *$ & 3,54 & 1,05 & \\
\hline \multicolumn{7}{|l|}{ Toplam } & 0,866 \\
\hline
\end{tabular}

***: $\mathbf{p}<.01$

21. Yüzyıl Yeterlilikleri Bilgi Alt Ölçeği'nin maddelerinin madde-toplam puan korelasyonu 0,266 ile 0,579 arasında değiştiği görülmektedir. Yine faktör yüklerinin 0,536 üzerinde olduğu, üst ve alt grup madde puan ortalamaları arasında anlamlı bir farklılık olduğu görülmektedir.

Ölçeğin güvenirliğini belirlemek için Cronbach alfa iç tutarlılık katsayısına bakılmıştır. Yapılan güvenilirlik analizleri sonucunda tüm ölçeğin Cronbach alfa değeri 0,866 bulunmuştur. Ölçeğin faktörleri acısından bakıldığında birinci faktör olan "Girişimcilik" için 0, 829; ikinci faktör olan "Kişisel Finans" için 0.841 ; üçüncü faktör olan "Sosyal Sistem" için 0,759; dördüncü faktör olan "Teknoloji ve Mühendislik" için 0,809; beşinci faktör 
olan "Biyoenerji” için 0,644; altıncı faktör olan "Medya" için 0.624 ve yedinci faktör olan "Sağlık" için 0,716 değerleri bulunmuştur.

21. Yüzyıl Yeterlilikleri Bilgi Alt Ölçeği ile ilgili tüm değerlere bakılarak ölçeğin güvenilir ve geçerli bir ölçek olduğu söylenebilir.

\section{Yüzyıl Yeterlilikleri Bilgi Alt Ölçeği'nin Puanlaması}

Geliştirilen 21. Yüzyıl Yeterlilikleri Bilgi Alt Ölçeğinin boyutlarına dair puan değerlendirmelerini tablosu Tablo 5 'de verilmiştir.

Tablo 5. 21. Yüzyıl Yeterlilikleri Bilgi Alt Ölçeği'nin puanlama tablosu

\begin{tabular}{|c|c|c|c|c|c|c|}
\hline \multirow{2}{*}{$\begin{array}{l}\text { 21. Yüzyıl Yeterlilikleri } \\
\text { Bilgi Alt Ölçeği'nin } \\
\text { Boyutları }\end{array}$} & \multirow[b]{2}{*}{ Maddeler } & \multicolumn{5}{|c|}{ Yeterlilik Düzeyi } \\
\hline & & $\begin{array}{l}\text { Çok } \\
\text { Düşüuk }\end{array}$ & Düşük & Orta & İyi & Çok İyi \\
\hline Girişimcilik & $\begin{array}{l}3,4,5,6,7,8,9 \text { ve } \\
10\end{array}$ & $8-14,4$ & $\begin{array}{l}14,41- \\
20,8\end{array}$ & $\begin{array}{l}20,81- \\
27,2 \\
\end{array}$ & $\begin{array}{l}27,21- \\
33,6 \\
\end{array}$ & $33,61-40$ \\
\hline Kişisel Finans & $\begin{array}{l}11,12,13,14 \text { ve } \\
15\end{array}$ & $5-9$ & $9,01-13$ & $13,01-17$ & $17,01-21$ & $21,01-25$ \\
\hline Sosyal Sistem & 25,26 ve 27 & $3-5,4$ & $5,41-7,8$ & $\begin{array}{l}7,81- \\
10,2 \\
\end{array}$ & $\begin{array}{l}10,21- \\
12,6 \\
\end{array}$ & $12,61-15$ \\
\hline Teknoloji ve Mühendislik & $21,22,23$ ve 24 & $4-7,2$ & $7,21-10,4$ & $\begin{array}{l}10,41- \\
13,6 \\
\end{array}$ & $\begin{array}{l}13,61- \\
16,8 \\
\end{array}$ & $16,81-20$ \\
\hline Biyoenerji & 1 ve 2 & $2-3,6$ & $3,61-5,2$ & $5,21-6,8$ & $6,81-8,4$ & $8,41-10$ \\
\hline Medya & 16,17 ve 18 & $3-5,4$ & $5,41-7,8$ & $\begin{array}{l}7,81- \\
10,2 \\
\end{array}$ & $\begin{array}{l}10,21- \\
12,6 \\
\end{array}$ & $12,61-15$ \\
\hline Sağlık & 19 ve 20 & $2-3,6$ & $3,61-5,2$ & $5,21-6,8$ & $6,81-8,4$ & $8,41-10$ \\
\hline Toplam & & $27-48,6$ & $\begin{array}{l}48,61- \\
70,2\end{array}$ & $\begin{array}{l}70,21- \\
91,8\end{array}$ & $\begin{array}{l}91,81- \\
113,4 \\
\end{array}$ & $\begin{array}{l}113,41- \\
135\end{array}$ \\
\hline
\end{tabular}

21. Yüzyıl Yeterlilikleri Bilgi Alt Ölçeği alt boyutlarıyla ve toplam bir şekilde puanlamaktadır. Alınan yüksek puan kişinin ilgili boyutta yeterliliğe yüksek düzeyde sahip olduğu, düşük puan ise ilgili alanda yeterliliğe düşük düzeyde sahip olduğunu göstermektedir. Ters puanlama gerektiren madde yoktur.

\section{A- $\quad$ 21. Yüzyil Yeterlilikleri Beceri Alt Ölçeği}

\section{Madde Analizi}

Taslak ölçek maddelerinin 21. Yüzyıl Yeterlilikleri Beceri Alt Ölçeği ile ilgili olup olmadığının belirlenmesi amacıyla gerçekleştirilen madde-toplam puan korelasyon değerlerine bakıldığında bu değerlerin 0,373 ile 0,609 arasında değiştiği görülmüştür. Bu değerlerin 0.30 'un üstünde olduğundan maddeler teste alınmıştır.

\section{Yapı Geçerliği}

\section{Yüzyıl Yeterlilikleri Beceri Alt Ölçeği’nin Açımlayıcı Faktör Analizi (AFA)}

21. Yüzyıl Yeterliliklerinin Beceri Alt Ölçeği için toplanan verilerin faktör analizi için uygunluğunun tespiti için Kaiser-Meyer-Olkin (KMO) katsayısına, Bartlett küresellik testi sonucuna ve veri matrisinin köşegen değerlerine bakılmıştır. Toplanan veriler için KMO katsayısı 0.890 olarak hesaplanmıştır. Bunun yanı sıra Bartlett testi Kikare değeri istatistiksel olarak anlamlı $(\mathrm{X} 2=2229.82 ; \mathrm{p}<0.01)$ çıkmıştır. Anti-imaj matrisindeki köşegen değerlerinin tamamı 0.50 değerinden büyüktür. Bu sonuçlar 21. Yüzyıl Yeterlilikleri Beceri Alt Ölçeği için toplanan verilerin faktör analizi için gerekli şartları sağladığını göstermektedir.

AFA analizinde faktör yüklerinin hesaplanmasında temel bileşenler analizi (Principal Component) metodu ve döndürme tekniği olarak varimax kullanılmıştır. İlk AFA sonucunda maddelerin dört faktöre dağıldığ 1 aynı zamanda scree plot grafiğine göre de faktör sayısının dört olabileceği görülmüştür. 


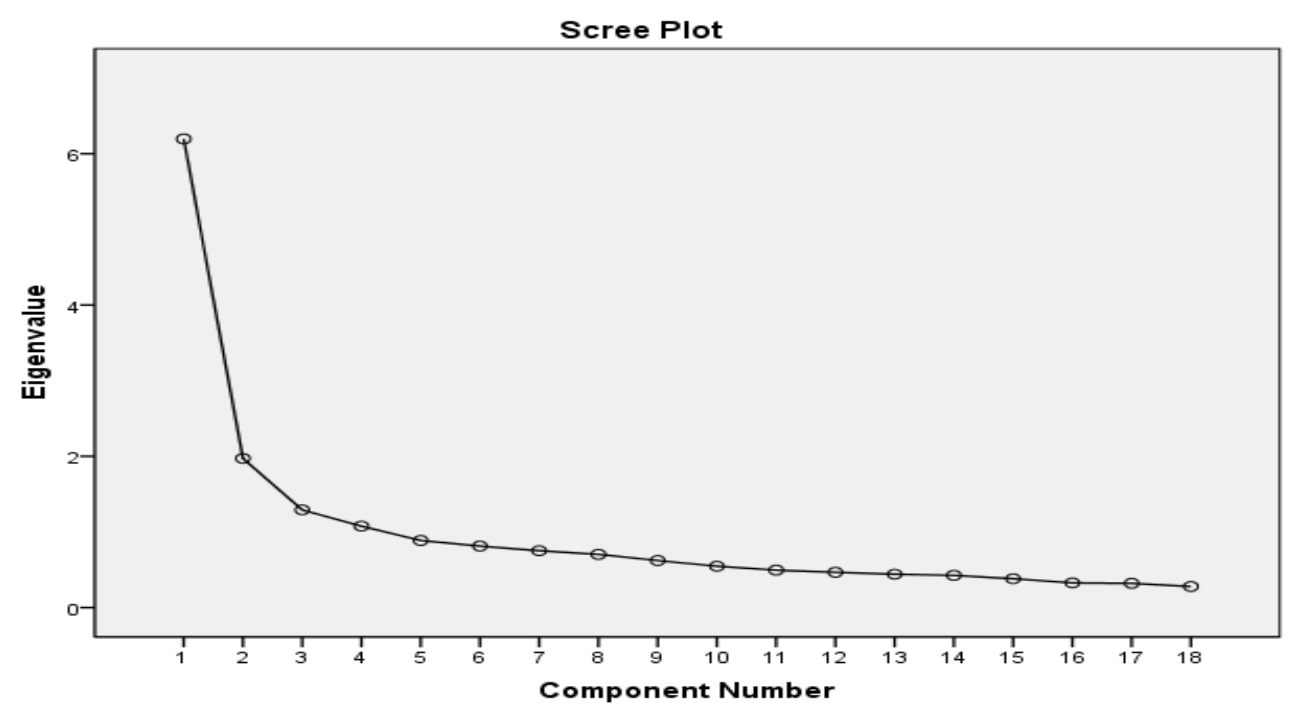

Şekil 3. 21. Yüzyll Yeterlilikleri Beceri Alt Ölçeği Yamaç Birikinti Grafiği

Şekil 3'de görüldüğ̈̈ gibi 1'den büyük öz değerlere sahip faktörler ve kuramsal temeller de göz önüne alındığında dört faktörlü bir yapının olabileceği kabul edilmiştir. 19 maddenin içinde Faktör yükü 0.40 'ın altında olan ya da birden fazla faktöre yüklenen 1 binişik madde testten çıkarılarak yeniden faktör analizi yapılmıştır. Sonuçta dört alt faktörlü ve açıklanan varyans oranı \%58,536 olan yapı elde edilmiştir. Faktör analizi sonucu her maddenin yalnızca bir faktöre yüklendiği görülmektedir. AFA sonucu elde edilen faktörler ve maddelerin faktör yükleri Tablo 6'da görülmektedir.

Açımlayıcı faktör analizinde elde edilen faktör yüklerinin .459 ile .836 arasında olduğu görülmektedir. Bu da elde edilen faktör yüklerinin belirtilen alt sınırların üstünde olduğunu göstermektedir. Buna göre faktörlere yüklenen maddeler istenen yapıyı uygun bir şekilde ölçmektedir. Elde edilen faktörler içerdiği maddelere bakılarak isimlendirilmiştir. Bu doğrultuda 6 maddeden ( $\mathrm{m} 10, \mathrm{~m} 11, \mathrm{~m} 12, \mathrm{~m} 3, \mathrm{~m} 14$ ve $\mathrm{m} 15)$ oluşan birinci faktöre "İletişim", 5 maddeden ( $\mathrm{m} 5, \mathrm{~m} 6, \mathrm{~m} 7, \mathrm{~m} 8$ ve $\mathrm{m} 9$ ) oluşan ikinci faktöre "Eleştirel Düşünme", 4 maddeden (m1, m2, m3 ve m4) oluşan ü̧̈üncü faktöre "Yaratıc1lık" ve 3 maddeden ( $\mathrm{m16}, \mathrm{m17}$, m18) oluşan dördüncü faktöre "İşbirliği Öğrenme" olarak adlandırılmıştır. 
Tablo 6. 21. Yüzyıl Yeterlilikleri Beceri Alt Ölçeği’nin döndürülmüş bileşenler matrisi (varimax)

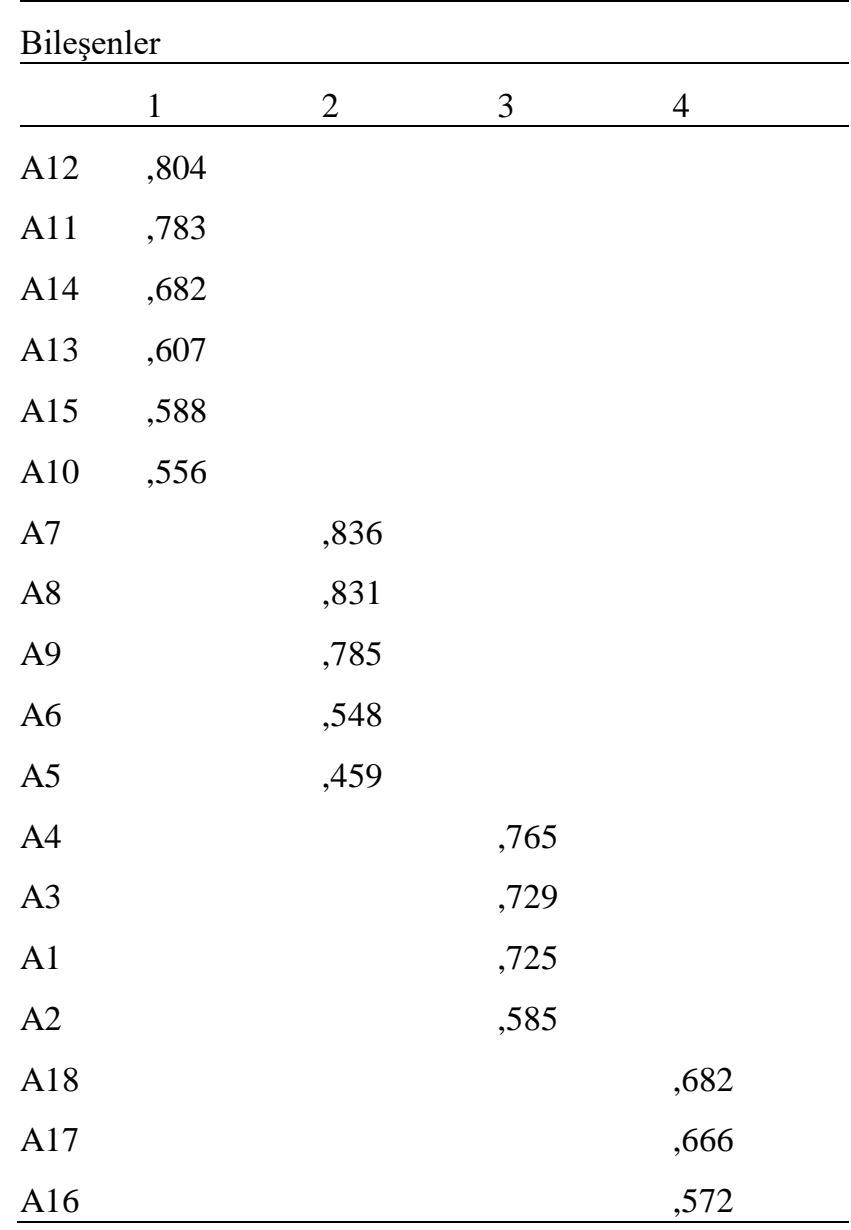

Açıklanan Varyans Toplam: \% 58,536, Faktör 1: \% 34,422,

Faktör 2: \% 10,954, Faktör 3: \% 7,177 ve Faktör 4: 5,982

Tablo 7. 21. Yüzyıl Yeterliliklerinin Beceri Alt Ölçeği’nin faktörleri arasındaki korelasyon katsayıları

\begin{tabular}{llllll}
\hline \multirow{2}{*}{ İletişim } & & İletişim & Eleştirel Düşünme & Yaratıcılık & İşbirliği Öğrenme \\
\cline { 2 - 6 } & $\mathrm{r}$ & 1 &, $437^{* *}$ &, $466^{* *}$ &, $542^{* *}$ \\
\hline \multirow{2}{*}{ Eleştirel Düşünme } & $\mathrm{p}$ & &, 000 &, 000 &, 000 \\
\cline { 2 - 6 } & $\mathrm{r}$ &, $437^{* *}$ & 1 &, $506^{* *}$ &, $387^{* *}$ \\
\hline Yaratıcılık & $\mathrm{p}$ &, 000 & &, 000 &, 000 \\
\cline { 2 - 6 } & $\mathrm{r}$ &, $466^{* *}$ &, $506^{* *}$ & 1 &, $368^{* *}$ \\
\hline İşbirlikçi Öğrenme & $\mathrm{p}$ &, 000 &, 000 & &, 000 \\
\cline { 2 - 6 } & $\mathrm{r}$ &, $542^{* *}$ &, $387^{* *}$ &, $368^{* *}$ & 1 \\
\hline
\end{tabular}

Tablo 7 incelendiğinde, ölçeğin alt boyutları arasındaki korelasyonların .368 ile .542 arasında değiştiği ve .05 düzeyinde anlamlı ilişkiye sahip olduğu görülmektedir. Açımlayıcı faktör analizi sonrasında ortaya çıkan modelin, yapı geçerliğini değerlendirmek için doğrulayıcı faktör analizi (DFA) yapılmıştır (Kline, 2011).

\section{Yüzyıl Yeterlilikleri Beceri Alt Ölçeği’nin Doğrulayıcı Faktör Analizi (DFA)}

DFA kapsamında AFA sonucu elde edilen 4 faktörlü 18 madde içeren "Beceri Alt Ölçeği” doğrulayıcı faktör analizine tabi tutulmuştur ve çeşitli uyum indekslerine dayalı yorumlar yapılmıştır. 
Tablo 8. 21. Yüzyıl Yeterlilikleri Beceri Alt Ölçeği DFA sonuçlarının uyum indeksi değerleri ve karşılaştırılması

\begin{tabular}{lllllll}
\hline Model & $\chi 2$ /sd & GFI & CFI & IFI & NNFI & RMSEA \\
\hline & $233,137 / 126=1,850$ &, 925 &, 946 &, 947 &, 911 &, 052 \\
\hline $\begin{array}{l}\text { Uyum } \\
\text { Yorumu * }\end{array}$ & Mükemmel Uyum & $\begin{array}{l}\text { Mükemmel } \\
\text { Uyum }\end{array}$ & $\begin{array}{l}\text { Kabul } \\
\text { Edilebilir } \\
\text { Uyum }\end{array}$ & $\begin{array}{l}\text { Kabul } \\
\text { Edilebilir } \\
\text { Uyum }\end{array}$ & $\begin{array}{l}\text { Kabul } \\
\text { Edilebilir }\end{array}$ & $\begin{array}{l}\text { Kabul } \\
\text { Edilebilir } \\
\text { Uyum }\end{array}$ \\
\hline
\end{tabular}

*(Bayram, 2013; Hu \& Bentler, 1999; Schumacker \& Lomax, 2004)

DFA sonucunda 4 faktörlü olarak elde edilen ölçeğin uyum indekslerinin kabul edilebilir değerler aldı̆̆ görülmektedir. Ki kare değerinin serbestlik derecesine oranı, $(\chi 2 / \mathrm{sd}=1,850)$ 2'den küçük çıkmıştır. GFI (Goodness of Fit Index), CFI (Comparative Fit Index), IFI (Incremental Fit Index) ve NNFI (Non-Normed Fit Index) uyum indeksleri ve RMSEA değeri $(.05 \leq$ RMSEA $\leq .08)$ uyum indeksleri öne sürülen model ve eldeki verileri iyi uyum gösterdiği söylenebilir.

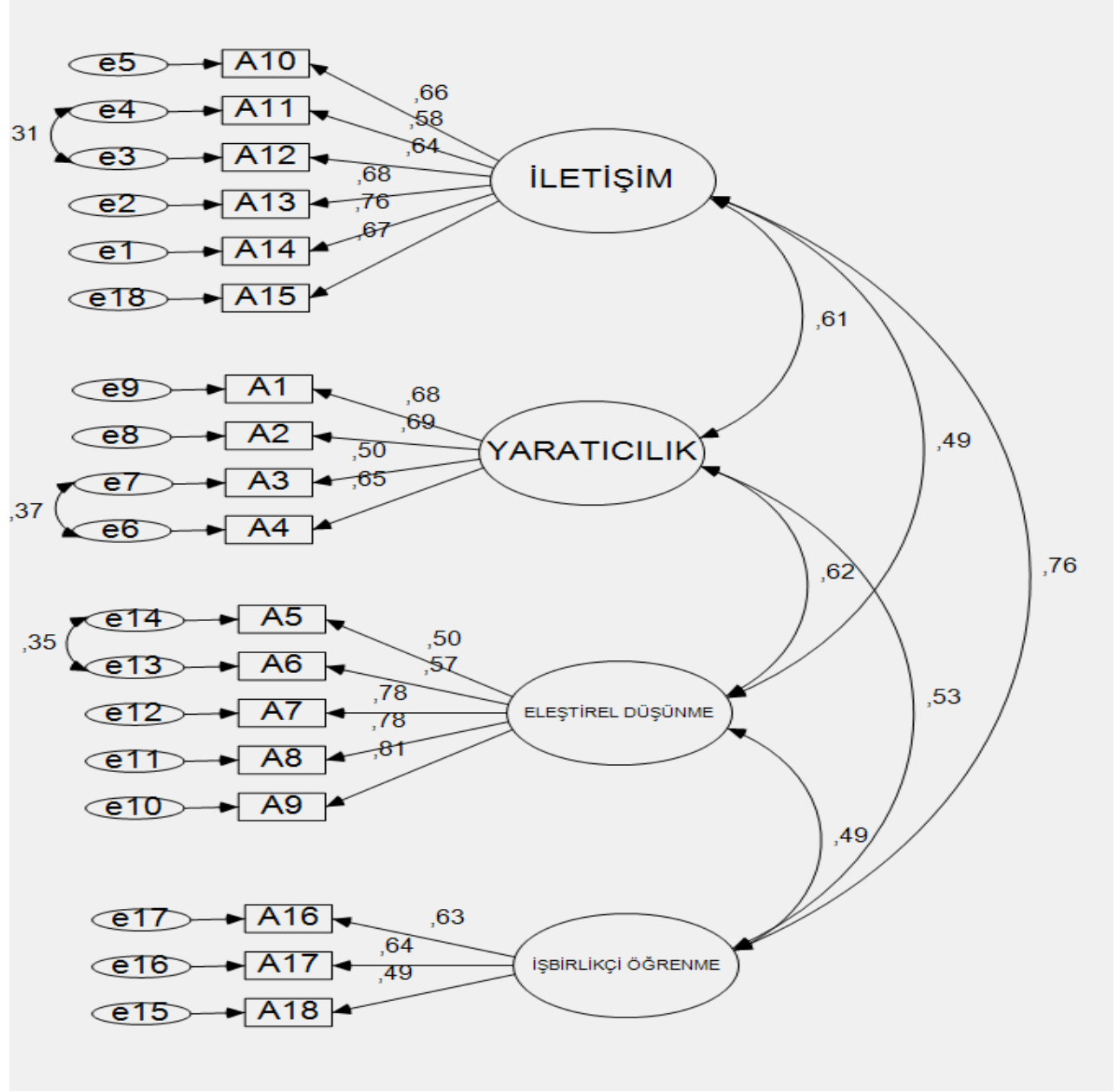

\section{Şekil 4. 21. Yüzyıl Yeterlilikleri Beceri Alt Ölçeği 'nin DFA sonuçları: Standartlaştırılmış Yol Diyagramları}

Ölçeğin her bir faktöründeki maddelerin bulunduğu faktörü temsil etme düzeyleri için standardize yol diyagramlarına bakılmıştır. Maddelerin standardize yol katsayıları 0.49 ile 0.81 arasında değişmektedir. $\mathrm{Bu}$ değerler maddelerin bulundukları faktörleri iyi bir şekilde temsil ettiğini göstermektedir. 
Tablo 9. 21. Yüzyıl Yeterlilikleri Beceri Alt Ölçeği maddelerine ait bazı geçerlik güvenirlik analizi değerleri

\begin{tabular}{|c|c|c|c|c|c|c|c|}
\hline Faktör & $\begin{array}{l}\text { Madde } \\
\text { No }\end{array}$ & $\begin{array}{l}\text { Madde- } \\
\text { toplam puan } \\
\text { korelasyonu }\end{array}$ & $\begin{array}{l}\text { AFA } \\
\text { faktör } \\
\text { yükü }\end{array}$ & $\begin{array}{l}\text { Alt üst } \\
\text { grup } \\
\text { farkı için } \\
\text { t değeri }\end{array}$ & $\begin{array}{l}\text { Madde } \\
\text { ortalama }\end{array}$ & $\begin{array}{l}\text { Madde } \\
\text { Standart } \\
\text { sapma }\end{array}$ & $\begin{array}{l}\text { Cronbach } \\
\text { alfa } \\
\text { iç tutarlılık } \\
\text { katsayısı }\end{array}$ \\
\hline \multirow{6}{*}{ İletişim } & A12 &, 480 & ,804 & $12,02 * *$ & 4,56 &, 57 & \multirow{6}{*}{0.833} \\
\hline & A11 &, 446 &, 783 & $9,80 * *$ & 4,59 &, 55 & \\
\hline & A14 & ,609 & ,682 & $13,70 * *$ & 4,53 &, 58 & \\
\hline & A13 &, 564 &, 607 & $12,99 * *$ & 4,43 & ,66 & \\
\hline & A15 &, 530 &, 588 & $14,59 * *$ & 4,47 &, 57 & \\
\hline & A10 &, 603 &, 556 & $14,00 * *$ & 4,42 &, 57 & \\
\hline \multirow{5}{*}{$\begin{array}{l}\text { Eleştirel } \\
\text { Düşünme }\end{array}$} & A7 &, 512 & ,836 & $12,40 * *$ & 4,21 &, 73 & \multirow{5}{*}{0.825} \\
\hline & A8 &, 529 &, 831 & $14,06^{* *}$ & 4,17 &, 74 & \\
\hline & A9 &, 586 &, 785 & $15,90 * *$ & 4,23 &, 72 & \\
\hline & A6 &, 567 &, 548 & $12,97 * *$ & 4,14 &, 70 & \\
\hline & A5 &, 520 & ,459 & $12,35^{* *}$ & 4,19 &, 69 & \\
\hline \multirow{4}{*}{ Yaratıcılık } & A4 &, 550 &, 765 & $14,39 * *$ & 4,27 &, 71 & \multirow{4}{*}{0.752} \\
\hline & A3 &, 461 &, 729 & $12,13^{* *}$ & 4,22 &, 71 & \\
\hline & A1 &, 473 &, 725 & $11,34 * *$ & 4,15 & ,69 & \\
\hline & $\mathrm{A} 2$ &, 533 &, 585 & $15,91 * *$ & 4,36 &, 60 & \\
\hline \multirow{3}{*}{$\begin{array}{l}\text { İşbirlikçi } \\
\text { Öğrenme }\end{array}$} & A18 &, 373 &, 682 & $8,46 * *$ & 4,48 &, 63 & \multirow{3}{*}{0.611} \\
\hline & A17 &, 454 & ,666 & $8,80 * *$ & 4,36 & ,68 & \\
\hline & A16 &, 487 &, 572 & $12,00 * *$ & 4,46 &, 62 & \\
\hline Toplam & & & & & & & 0.884 \\
\hline
\end{tabular}

**: $\mathbf{p}<.01$

Tablo 9 incelendiğinde 21. Yüzyıl Yeterlilikleri Beceri Alt Ölçeği'nin maddelerinin madde-toplam puan korelasyonu 0,373 ile 0,609 arasındadır. Beceri alt ölçeğinin faktör yüklerinin 0,459 üzerindedir. Beceri alt ölçeğinin tüm maddelerinde üst ve alt grup madde puan ortalamaları arasında anlamlı bir farklılık görülmüştür.

21. Yüzyıl Yeterlilikleri Beceri Ölçeğin güvenirliğini belirlemek için Cronbach alfa iç tutarlılık katsayısına bakılmıştır. Yapılan güvenilirlik analizleri sonucunda tüm ölçeğin Cronbach alfa değeri 0.884 bulunmuştur. Ölçeğin faktörleri acısından bakıldığında birinci faktör olan iletişim için 0.833; ikinci faktör olan eleştirel düşünme için 0.825; üçüncü faktör olan yaratıcılık için 0.752 ve dördüncü faktör olan işbirliği öğrenme için 0.611 değerleri bulunmuştur.

21. Yüzyıl Yeterlilikleri Beceri Alt Ölçeği’nin ilgili tüm değerlere bakılarak ölçeğin güvenilir ve geçerli bir ölçek olduğu söylenebilir.

\section{Yüzyıl Yeterlilikleri Beceri Alt Ölçeği’nin Puanlaması}

Geliştirilen 21. Yüzyıl Yeterlilikleri Beceri Alt Ölçeği’nin boyutlarına dair puan değerlendirmelerini tablosu Tablo 10 'da verilmiştir. 
Tablo 10. 21. Yüzyıl Yeterlilikleri Beceri Alt Ölçeği’nin puanlama tablosu

\begin{tabular}{|c|c|c|c|c|c|c|}
\hline \multirow{2}{*}{$\begin{array}{l}\text { Beceri Alt Ölçeğinin } \\
\text { Boyutları }\end{array}$} & \multirow[t]{2}{*}{ Maddeler } & \multicolumn{5}{|c|}{ Yeterlilik Düzeyi } \\
\hline & & $\begin{array}{l}\text { Çok } \\
\text { Düşük }\end{array}$ & Düşük & Orta & İyi & Çok İyi \\
\hline İletişim & $\begin{array}{l}10,11,12,3,14 \text { ve } \\
15\end{array}$ & $6-10,8$ & $\begin{array}{l}10,81- \\
15,6\end{array}$ & $\begin{array}{l}15,61- \\
20,4\end{array}$ & $\begin{array}{l}20,41- \\
25,2\end{array}$ & $\begin{array}{l}25,21- \\
30\end{array}$ \\
\hline Eleştirel Düşünme & $5,6,7,8$ ve 9 & $5-9$ & $9,01-13$ & $13,01-17$ & $17,01-21$ & $\begin{array}{l}21,01- \\
25\end{array}$ \\
\hline Yaratıcılık & $1,2,3$ ve 4 & $4-7,2$ & $7,21-10,4$ & $\begin{array}{l}10,41- \\
13,6\end{array}$ & $\begin{array}{l}13,61- \\
16,8\end{array}$ & $\begin{array}{l}16,81- \\
20\end{array}$ \\
\hline İşbirlikçi Öğrenme & $16,17,18$ & $3-5,4$ & $5,41-7,8$ & $7,81-10,2$ & $\begin{array}{l}10,21- \\
12,6\end{array}$ & $\begin{array}{l}12,61- \\
15\end{array}$ \\
\hline Toplam & & $18-32,4$ & $\begin{array}{l}32,41- \\
46,8\end{array}$ & $\begin{array}{l}46,81- \\
61,2\end{array}$ & $\begin{array}{l}61,21- \\
75,6\end{array}$ & $\begin{array}{l}75,61- \\
90\end{array}$ \\
\hline
\end{tabular}

21. Yüzyıl Yeterlilikleri Beceri Alt Ölçeği alt boyutlarıyla ve toplam bir şekilde puanlamaktadır. Ters puanlama gerektiren madde yoktur. Her bir alt boyutla ilgili maddeler verilen cevaplara göre toplanmakta ve ölçeğin ilgili alt boyutunun puanı hesaplanmaktadır. Ölçekten toplam puan elde edilirken tüm maddelerden alınan puanlar toplanmaktadır. Alınan yüksek puan kişinin ilgili boyutta yeterliliğe yüksek düzeyde sahip olduğu, düşük puan ise ilgili alanda yeterliliğe düşük düzeyde sahip olduğunu göstermektedir.

\section{B- $\quad$ 21. Yüzyil Yeterlilikleri Karakter Alt Ölçeği Madde Analizi}

Taslak ölçek maddelerinin madde-toplam puan korelasyonlarının 0.30 'un üstünde olduğundan dolayı 21 madde teste alınmıştır.

\section{Yapı Geçerliği}

\section{Yüzyıl Yeterlilikleri Karakter Alt Ölçeği'nin Açımlayıcı Faktör Analizi (AFA)}

21. Yüzyıl Yeterlilikleri Karakter Ölçeği'nin beceri alt ölçeği için toplanan veriler için KMO katsayısı 0.900 olarak hesaplanmıştır. Bunun yanı sıra Bartlett testi Ki-kare değeri istatistiksel olarak anlamlı $(\mathrm{X} 2=2248.93$; $<<0.01)$ çıkmıştır. Anti-imaj matrisindeki köşegen değerlerinin tamamı 0.50 değerinden büyüktür. Bu sonuçlar 21. Yüzyıl Yeterlilikleri Karakter Alt Ölçeği, faktör analizi için gerekli şartları sağlamıştır.

AFA analizinde kapsamında temel bileşenler analizi (Principal Component) metodu, döndürme tekniği olarak varimax kullanılmıştır. AFA sonuçlarına ve scree plot grafiğine göre ölçek maddelerinin dört faktöre dağıldığı görülmüştür. 


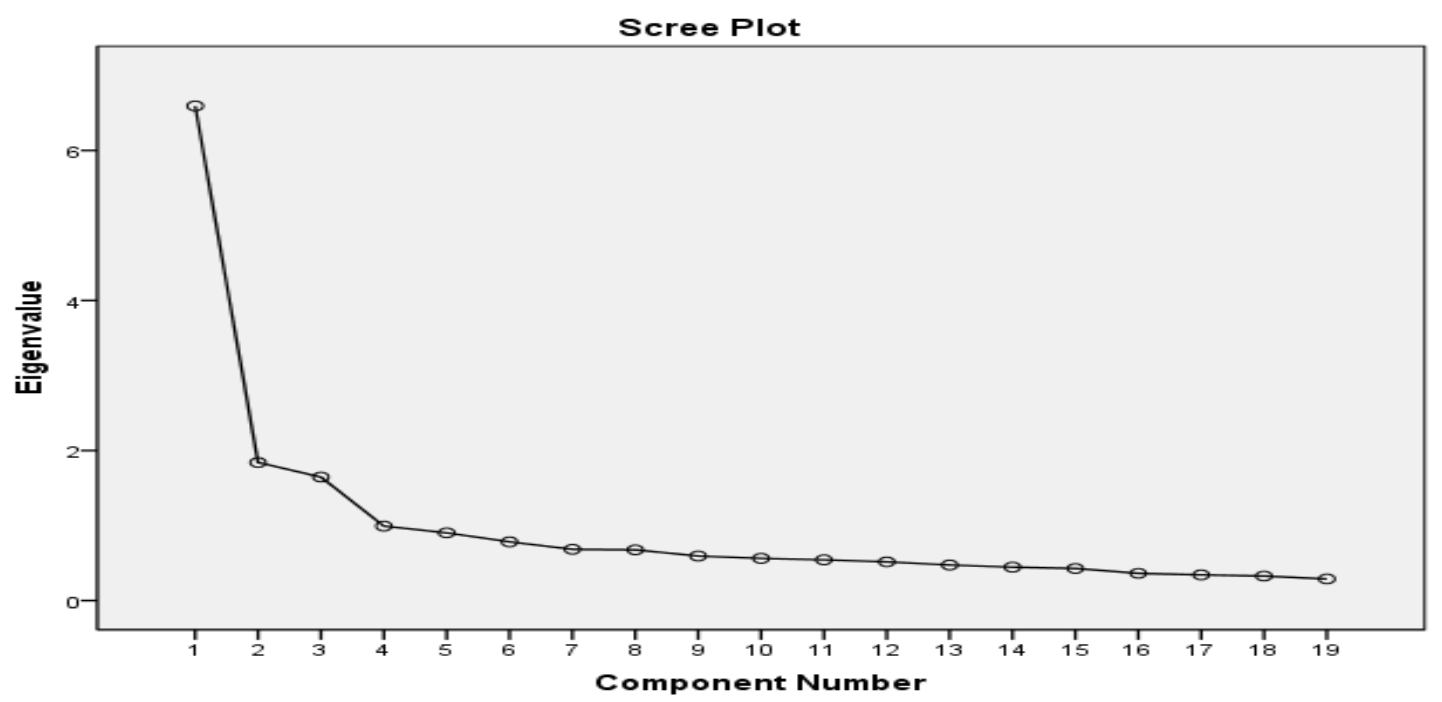

Şekil 5. 21. Yüzyll Yeterlilikleri Beceri Alt Ölçeği’nin Yamaç Birikinti Grafiği

AFA sonucunda faktör yükü 0.40 'ın altında olan ya da birden fazla faktöre yüklenen 2 binişik madde ölçekten çıkarılmış ve faktör yükleri tekrar hesaplanmıştır. Sonuçta 4 alt faktörlü ve açıklanan varyans oranı \% 58.275 olan yapı elde edilmiştir. Faktör analizi sonucu her maddenin yalnızca bir faktöre yüklendiği görülmektedir. AFA sonucu elde edilen faktörler ve maddelerin faktör yükleri Tablo 11'de görülmektedir.

Açımlayıcı faktör analizinde elde edilen faktör yüklerinin .459 ile .810 arasında olduğu görülmektedir. Bu da elde edilen faktör yüklerinin belirtilen alt sınırların üstünde olduğunu göstermektedir. Buna göre faktörlere yüklenen maddeler istenen yapıyı uygun bir şekilde ölçmektedir. Elde edilen faktörler içerdiği maddelere bakılarak isimlendirilmiştir. Bu doğrultuda 7 maddeden ( $\mathrm{m} 13, \mathrm{~m} 14, \mathrm{~m} 15, \mathrm{~m} 16, \mathrm{~m} 17, \mathrm{~m} 18$ ve m19) oluşan birinci faktöre "Liderlik", 4 maddeden (m9, m10, m11 ve m12) oluşan ikinci faktöre "Merak", 5 maddeden (m4, m5, m6, m7 ve m8) oluşan üçüncü faktöre "Ahlak" ve 3 maddeden (m1, m2 ve m3) oluşan dördüncü faktöre "Farkındalık" olarak adlandırılmıştır. 
Tablo 11. 21. Yüzyıl Yeterlilikleri Ölçeği’nin Karakter Alt Ölçeğinin döndürülmüş bileşenler matrisi (varimax)

\begin{tabular}{|c|c|c|c|c|}
\hline & \multicolumn{4}{|c|}{ Bileşenler } \\
\hline & 1 & 2 & 3 & 4 \\
\hline K14 & ,769 & & & \\
\hline K16 & ,762 & & & \\
\hline K15 & ,739 & & & \\
\hline K17 & ,735 & & & \\
\hline K13 & ,662 & & & \\
\hline K18 & ,624 & & & \\
\hline K19 & ,546 & & & \\
\hline K11 & & ,798 & & \\
\hline K12 & & ,772 & & \\
\hline K10 & & ,712 & & \\
\hline K9 & & ,513 & & \\
\hline K6 & & & ,764 & \\
\hline K7 & & & ,753 & \\
\hline K5 & & & ,737 & \\
\hline K4 & & &, 585 & , \\
\hline K8 & & &, 501 & \\
\hline $\mathrm{K} 1$ & & & & ,810 \\
\hline $\mathrm{K} 3$ & & & &, 511 \\
\hline $\mathrm{K} 2$ & & & & ,459 \\
\hline
\end{tabular}

Açıklanan Varyans Toplam: \% 58,275, Faktör 1: \% 34,700,

Faktör 2: \% 9,686, Faktör 3: \% 8,664, ve Faktör 4: 5,226

Tablo 12. 21. Yüzyıl Yeterlilikleri Karakter Alt Ölçeği’nin faktörleri arasındaki korelasyon katsayıları

\begin{tabular}{lcllll}
\hline \multirow{2}{*}{ Liderlik } & & Liderlik & Ahlak & Merak & Farkındalık \\
\cline { 2 - 6 } & $\mathrm{r}$ & 1 &, $442^{* *}$ &, $466^{* *}$ &, $508^{* *}$ \\
\hline \multirow{2}{*}{ Ahlak } & $\mathrm{p}$ & &, 000 &, 000 &, 000 \\
\cline { 2 - 6 } & $\mathrm{r}$ &, $442^{* *}$ & 1 &, $389^{* *}$ &, $545^{* *}$ \\
\hline \multirow{2}{*}{ Merak } & $\mathrm{p}$ &, 000 & &, 000 &, 000 \\
\hline \multirow{2}{*}{ Farkındalık } & $\mathrm{r}$ &, $466^{* *}$ &, $389^{* *}$ & 1 &, $481^{* *}$ \\
\cline { 2 - 6 } & $\mathrm{p}$ &, 000 &, 000 & &, 000 \\
\hline & $\mathrm{p}$ &, 000 &, 000 &, 000 & \\
\hline
\end{tabular}

Tablo 12 incelendiğinde, ölçeğin alt boyutları arasındaki korelasyonların .389 ile .545 arasında değiştiği ve .05 düzeyinde anlamlı ilişkiye sahip olduğu görülmektedir. Açımlayıcı faktör analizi sonrasında ortaya çıkan modelin, yapı geçerliğini değerlendirmek için doğrulayıcı faktör analizi (DFA) yapılmıştır (Kline, 2011). 


\section{Yüzyıl Yeterlilikleri Karakter Alt Ölçeği'nin Doğrulayıcı Faktör Analizi (DFA)}

21. Yüzyıl Yeterlilikleri Karakter Alt Ölçeği'nin, DFA analizleri sonucunda elde edilen uyum indekslerine Tablo 13'da verilmiştir.

Tablo 13. 21. Yüzyıl Yeterlilikleri Karakter Alt C DFA sonuçlarının uyum indeksi değerleri ve karşılaştırılması

\begin{tabular}{lllllll}
\hline Model & $\chi 2$ (sd & GFI & CFI & IFI & NNFI & RMSEA \\
\hline & $264,655 / 140=1,890$ &, 918 &, 941 &, 942 &, 892 &, 053 \\
\hline $\begin{array}{l}\text { Uyum } \\
\text { Yorumu* }\end{array}$ & Mükemmel Uyum & $\begin{array}{l}\text { Mükemmel } \\
\text { Uyum }\end{array}$ & $\begin{array}{l}\text { Kabul } \\
\text { Edilebilir } \\
\text { Uyum }\end{array}$ & $\begin{array}{l}\text { Kabul } \\
\text { Edilebilir }\end{array}$ & $\begin{array}{l}\text { Kabul } \\
\text { Edilebilir }\end{array}$ & $\begin{array}{l}\text { Kabul } \\
\text { Edilebilir }\end{array}$ \\
\hline
\end{tabular}

*(Bayram, 2013; Hu \& Bentler, 1999; Schumacker \& Lomax, 2004)

DFA sonucunda 4 faktörlü olarak elde edilen ölçeğin uyum indekslerinin genellikle iyi değerler aldığı görülmektedir. Ki kare değerinin serbestlik derecesine oranı, $(\chi 2 / s d=1,890) 2$ 'den küçük çıkmıştır. GFI (Goodness of Fit Index), CFI (Comparative Fit Index), IFI (Incremental Fit Index), NNFI (Non-Normed Fit Index) uyum indeksleri ve RMSEA değeri ile öne sürülen model ve eldeki verileri iyi uyum gösterdiği düşünülmektedir.

Ölçeğin her bir faktöründeki maddelerin bulunduğu faktörü temsil etme düzeyleri için standardize yol diyagramlarına bakılmıştır. 


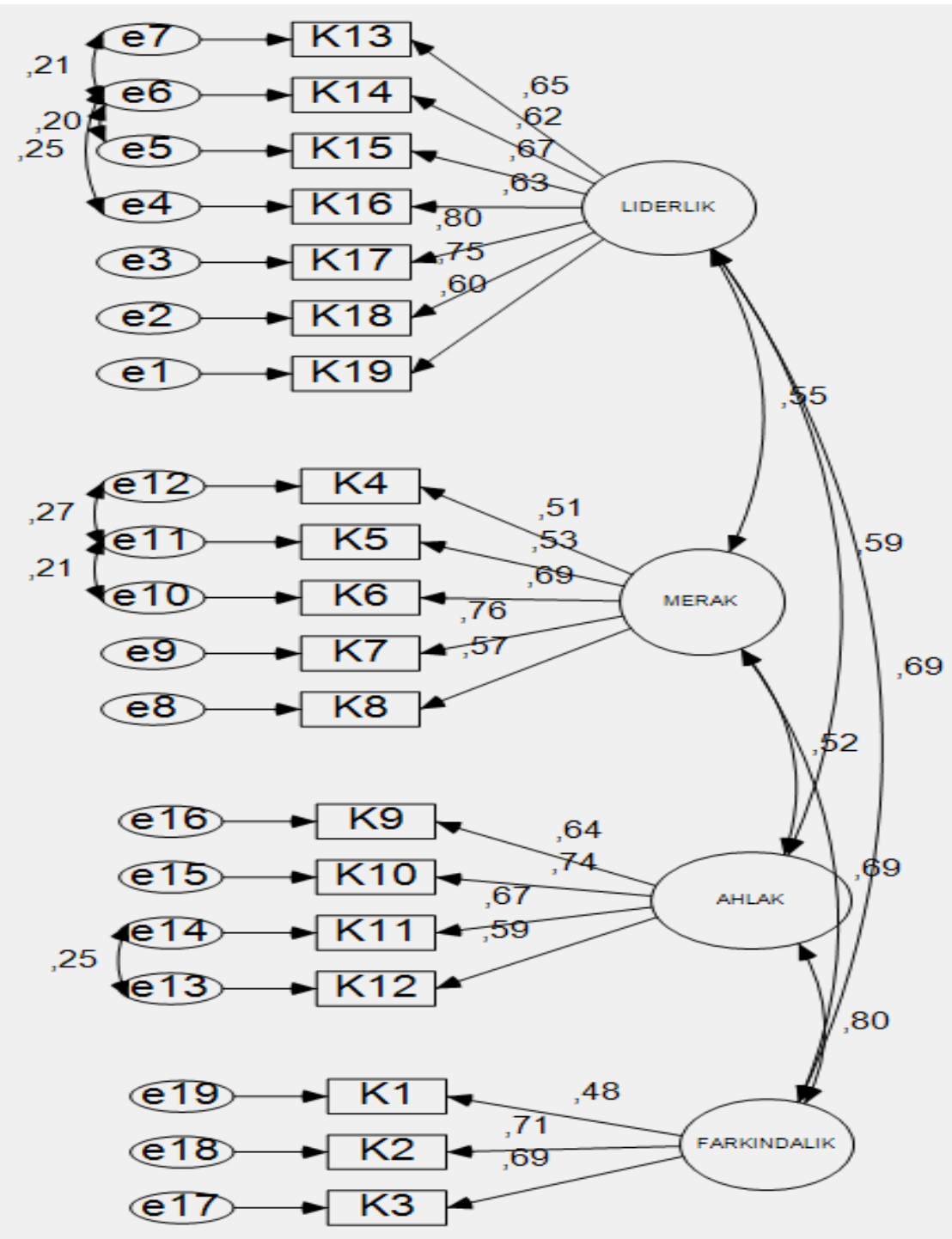

Şekil 6. 21. Yüzyıl Yeterlilikleri Karakter Alt Ölçeği'nin DFA Sonuçları: Standartlaştırılmış Yol Diyagramları

Maddelerin standardize yol katsayıları 0.48 ile 0.80 arasında değişmektedir. Bu değerler maddelerin bulundukları faktörleri iyi bir şekilde temsil ettiğini göstermektedir. 
Tablo 14. 21. Yüzyıl Yeterlilikleri Karakter Alt Ölçeği’nin maddelerine ait bazı geçerlik güvenirlik analizi değerleri

\begin{tabular}{|c|c|c|c|c|c|c|c|}
\hline Faktör & $\begin{array}{l}\text { Madde } \\
\text { No }\end{array}$ & $\begin{array}{l}\text { Madde- } \\
\text { toplam puan } \\
\text { korelasyonu }\end{array}$ & $\begin{array}{l}\text { AFA } \\
\text { faktör } \\
\text { yükü }\end{array}$ & $\begin{array}{l}\text { Alt üst } \\
\text { grup } \\
\text { farkı için } \\
\text { t değeri }\end{array}$ & $\begin{array}{l}\text { Madde } \\
\text { ortalama }\end{array}$ & $\begin{array}{l}\text { Madde } \\
\text { Standart } \\
\text { sapma }\end{array}$ & $\begin{array}{l}\text { Cronbach } \\
\text { alfa } \\
\text { iç tutarlılık } \\
\text { katsayısı }\end{array}$ \\
\hline \multirow{7}{*}{ Liderlik } & K14 &, 564 &, 769 & $14,39 * *$ & 4,18 &, 80 & \multirow{7}{*}{0.841} \\
\hline & K16 &, 505 &, 762 & $11,80 * *$ & 4,00 &, 97 & \\
\hline & K15 &, 571 &, 739 & $12,23 * *$ & 4,28 &, 72 & \\
\hline & $\mathrm{K} 17$ & ,637 &, 735 & $15,21 * *$ & 4,21 &, 76 & \\
\hline & $\mathrm{K} 13$ & ,599 & ,662 & $13,62 * *$ & 4,19 &, 70 & \\
\hline & K18 &, 652 &, 624 & $15,48 * *$ & 4,30 & ,68 & \\
\hline & K19 &, 557 &, 546 & $13,59 * *$ & 4,12 &, 82 & \\
\hline \multirow{4}{*}{ Ahlak } & $\mathrm{K} 11$ &, 448 & ,798 & $9,62 * *$ & 4,48 & ,61 & \multirow{4}{*}{0.766} \\
\hline & $\mathrm{K} 12$ & ,439 &, 772 & $10,24 * *$ & 4,55 &, 53 & \\
\hline & K10 &, 528 &, 712 & $10,63 * *$ & 4,38 & ,62 & \\
\hline & K9 & ,487 &, 513 & $9,84^{* *}$ & 4,24 &, 65 & \\
\hline \multirow{5}{*}{ Merak } & K6 &, 504 &, 764 & $12,45 * *$ & 4,16 &, 72 & \multirow{5}{*}{0.767} \\
\hline & K7 &, 519 &, 753 & $12,42 * *$ & 4,21 &, 72 & \\
\hline & K5 &, 451 &, 737 & $10,37 * *$ & 4,12 &, 76 & \\
\hline & K4 &, 450 &, 585 & $10,15^{* *}$ & 4,05 &, 80 & \\
\hline & K8 & ,453 &, 501 & $9,64 * *$ & 4,44 &, 57 & \\
\hline \multirow{3}{*}{ Farkındalık } & $\mathrm{K} 1$ & ,421 &, 810 & $9,25^{* *}$ & 4,06 &, 74 & \multirow{3}{*}{0.645} \\
\hline & K3 &, 539 &, 511 & $12,31 * *$ & 4,17 &, 70 & \\
\hline & $\mathrm{K} 2$ &, 581 & ,459 & $13,96 * *$ & 4,39 &, 58 & \\
\hline Toplam & & & & & & & 0.891 \\
\hline
\end{tabular}

$* * \mathbf{p}<.01$

21. Yüzyıl Yeterlilikleri Karakter Alt Ölçeği'nin maddelerinin madde-toplam puan korelasyonu 0,439 ile 0,652 arasında değiştiği görülmektedir. Yine faktör yüklerinin 0,459 üzerindedir. 21. Yüzyıl Yeterlilikleri Karakter Alt Ölçek maddelerinin üst ve alt grup madde puan ortalamaları arasında anlamlı bir farklılık olduğu görülmektedir.

Karakter Ölçeğin güvenirliğini belirlemek için Cronbach alfa iç tutarlılık katsayısına bakılmıştır. Yapılan güvenilirlik analizleri sonucunda tüm ölçeğin Cronbach alfa değeri 0.891 bulunmuştur. Ölçeğin faktörleri acısından bakıldığında birinci faktör olan "Liderlik" için 0.841; ikinci faktör olan "Merak" için 0.766; üçüncü faktör olan "Ahlak" için 0.767 ve dördüncü faktör olan "Farkındalık" için 0.645 değerleri bulunmuştur. 21. Yüzyıl Yeterlilikleri Karakter Alt Ölçeği ile ilgili tüm veriler, ölçeğin güvenilir ve geçerli olduğunu göstermiştir.

Geliştirilen 21. Yüzyıl Yeterlilikleri Karakter Alt Ölçeği'nin boyutlarına dair puan değerlendirmelerini tablosu Tablo 15'de verilmiştir. 
Tablo 15. 21. Yüzyıl Yeterlilikleri Karakter Alt Ölçeği’nin puanlama tablosu

\begin{tabular}{|c|c|c|c|c|c|c|}
\hline \multirow{2}{*}{$\begin{array}{lr}21 . & \text { Yüzyıl } \\
\text { Yeterlilikleri } & \\
\text { Karakter } & \text { Alt } \\
\text { Ölçeği'nin Boyutları }\end{array}$} & \multirow[b]{2}{*}{ Maddeler } & \multicolumn{5}{|c|}{ Yeterlilik Düzeyi } \\
\hline & & $\begin{array}{l}\text { Çok } \\
\text { Düşük }\end{array}$ & Düşük & Orta & İyi & Çok İyi \\
\hline Liderlik & $\begin{array}{l}13,14,15,16,17 \\
18 \text { ve } 19\end{array}$ & $7-12,6$ & $\begin{array}{l}12,61- \\
18,2\end{array}$ & $\begin{array}{l}18,21- \\
23,8\end{array}$ & $\begin{array}{l}23,81- \\
29,4\end{array}$ & $\begin{array}{l}29,41- \\
35\end{array}$ \\
\hline Merak & $4,5,6,7$ ve 8 & $5-9$ & $9,01-13$ & $13,01-17$ & $17,01-21$ & $\begin{array}{l}21,01- \\
25\end{array}$ \\
\hline Ahlak & $9,10,11$ ve 12 & $4-7,2$ & $7,21-10,4$ & $\begin{array}{l}10,41- \\
13,6\end{array}$ & $\begin{array}{l}13,61- \\
16,8\end{array}$ & $\begin{array}{l}16,81- \\
20\end{array}$ \\
\hline Farkındalık & 1,2 ve 3 & $3-5,4$ & $5,41-7,8$ & $7,81-10,2$ & $\begin{array}{l}10,21- \\
12,6\end{array}$ & $\begin{array}{l}12,61- \\
15\end{array}$ \\
\hline Toplam & & $18-32,4$ & $\begin{array}{l}32,41- \\
46,8\end{array}$ & $\begin{array}{l}46,81- \\
61,2 \\
\end{array}$ & $\begin{array}{l}61,21- \\
75,6 \\
\end{array}$ & $\begin{array}{l}75,61- \\
90\end{array}$ \\
\hline
\end{tabular}

21. Yüzyıl Yeterlilikleri Karakter Alt Ölçeği, alt boyutlarıyla ve toplam bir şekilde puanlanabilmektedir. Ters puanlama gerektiren madde yoktur. Her bir alt boyutla ilgili maddeler verilen cevaplara göre toplanmakta ve ölçeğin ilgili alt boyutunun puanı hesaplanmaktadır. Ölçekten toplam puan elde edilirken tüm maddelerden alınan puanlar toplanmaktadır. Alınan yüksek puan kişinin ilgili boyutta yeterliliğe yüksek düzeyde sahip olduğu, düşük puan ise ilgili alanda yeterliliğe düşük düzeyde sahip olduğunu göstermektedir.

\section{C- 21. Yüzyil Yeterlilikleri Metaöğrenme Alt Ölçeğinin Madde Analizi}

21. Yüzyıl Yeterlilikleri Metaöğrenme Alt Ölçeği’nin 18 maddesi, madde-toplam puan korelasyonlarına bakılmıştır. Metaöğrenme alt ölçeğinin madde-toplam puan korelasyon değerleri 0.30 'un üstünde olduğu görülmüştür. Bu sebepten dolayı 18 madde ile analizlere başlanmıştır.

\section{Yapı Geçerliği}

\section{Yüzyıl Yeterlilikleri Metaöğrenme Alt Ölçeği’nin Açımlayıcı Faktör Analizi (AFA)}

21. Yüzyıl Yeterliliklerinin Metaöğrenme Alt Ölçeği'yle ilgili toplanan veriler için KMO katsayısı 0.922 olarak hesaplanmıştır. Bunun yanı sıra Bartlett testi Ki-kare değeri istatistiksel olarak anlamlı $(\mathrm{X} 2=2212.661 ; \mathrm{p}<0.01)$ çıkmıştır. Anti-imaj matrisindeki köşegen değerlerinin tamamı 0.50 değerinden büyüktür. Bu sonuçlar 21. Yüzyıl Yeterlilikleri Metaöğrenme Alt Ölçeği'nin için toplanan verilerin faktör analizi için gerekli şartları sağladığını göstermektedir.

21. Yüzyıl Yeterlilikleri Metaöğrenme Alt Ölçeğinin için yapılan AFA analizinde temel bileşenler analizi (Principal Component) metodu döndürme tekniği olarak varimax kullanılmıştır. Hem AFA sonuçları hem de scree plot grafiğine göre ölçek maddelerin iki faktöre dağıldığı görülmüştür. 


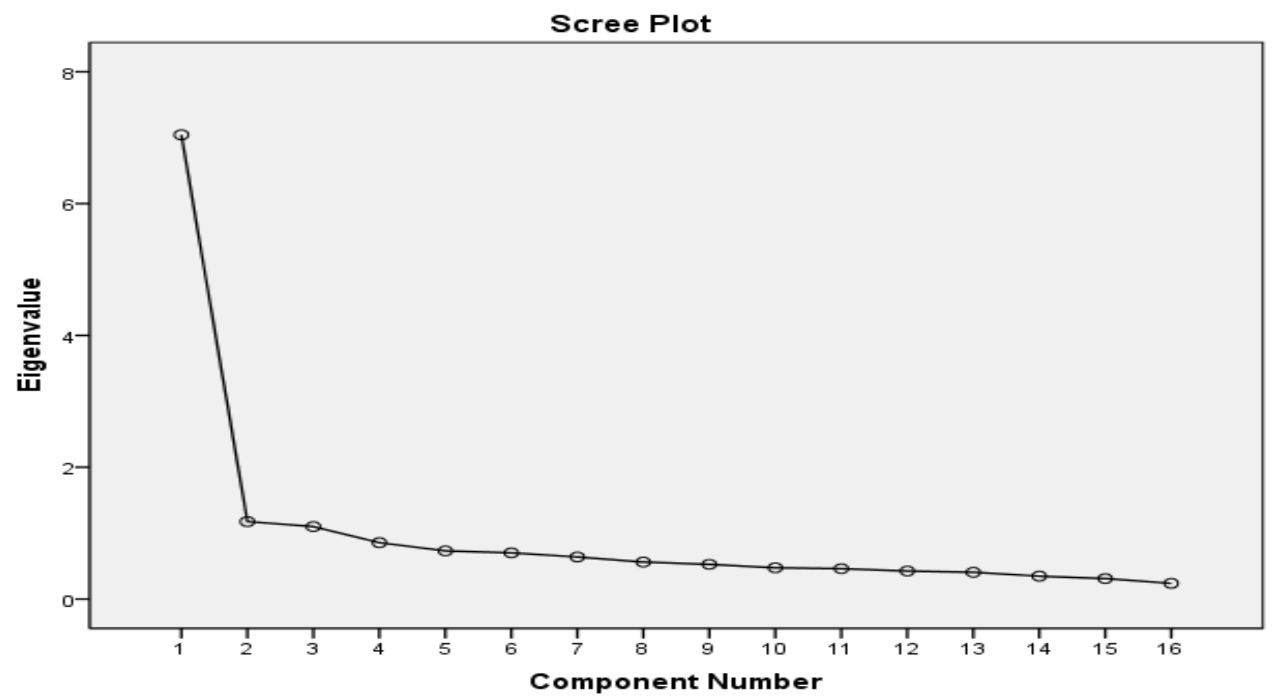

\section{Şekil 7. 21. Yüzyll Yeterlilikleri Öllçeği Metä̈ğrenme Alt Ölçeği’nin Yamaç Birikinti Grafiği}

Faktör yükü 0.40 'ın altında olan ya da birden fazla faktöre yüklenen 2 binişik madde ölçekten çıkarılmıştır. 21 . Yüzyıl Yeterlilikleri Metaöğrenme Alt Ölçek çıkarılmış madde haliyle faktör yükleri tekrar hesaplanmıştır. Sonuçta iki alt faktörlü ve açılanan varyans oranı \% 51.368 olan yapı elde edilmiştir. AFA sonucu elde edilen faktörler ve maddelerin faktör yükleri Tablo 16 'de görülmektedir.

21. Yüzyıl Yeterlilikleri Metaöğrenme Alt Ölçeği’nin faktör yüklerinin 0,544 ile 0.847 arasında olduğu görülmektedir. Bu da elde edilen faktör yüklerinin belirtilen alt sınırların üstünde olduğunu göstermektedir. Buna göre faktörlere yüklenen maddeler istenen yapıyı uygun bir şekilde ölçmektedir. Elde edilen faktörler içerdiği maddelere bakılarak isimlendirilmiştir. Bu doğrultuda dört maddeden ( $\mathrm{m} 1, \mathrm{~m} 2, \mathrm{~m} 3 \mathrm{ve} \mathrm{m} 4)$ oluşan birinci faktöre "Düşünce Yapısı" ve 12 maddeden ( 5 5, m6, m7, m8, m9, m10, m11, m12, m13, m14, m15 ve m16) oluşan ikinci faktöre "Üstbiliş̧" olarak adlandırılmıştır. 
Tablo 16. 21. Yüzyıl Yeterlilikleri Metaöğrenme Alt Ölçeği’nin Döndürülmüş Bileşenler Matrisi (Varimax)

\begin{tabular}{lll}
\hline Bileşenler & & \\
\hline & 1 & 2 \\
\hline M1 & &, 766 \\
M2 & &, 762 \\
M3 & &, 614 \\
M4 & & \\
M5 &, 638 & \\
M6 &, 580 & \\
M7 &, 691 & \\
M8 &, 728 & \\
M9 &, 669 & \\
M10 &, 657 & \\
M11 &, 544 & \\
M12 &, 588 & \\
M13 &, 635 & \\
M14 &, 598 & \\
M15 &, 647 & \\
M16 &, 576 & \\
\hline
\end{tabular}

Açıklanan Varyans Toplam: \% 51,369,

Faktör 1: \% 44,021 ve Faktör 2: \% 7,348

Tablo 17. 21. Yüzyıl Yeterlilikleri Metaöğrenme Alt Ölçeği’nin faktörleri arasındaki korelasyon katsayıları

\begin{tabular}{llll}
\hline & & $\begin{array}{l}\text { Düşünce } \\
\text { Yapısı }\end{array}$ & Üstbiliş \\
\hline $\begin{array}{l}\text { Düşünce } \\
\text { Yapıs1 }\end{array}$ & $\mathrm{r}$ & 1 &, $667^{* *}$ \\
\cline { 2 - 4 } & $\mathrm{p}$ & &, 000 \\
\hline Üstbiliş & $\mathrm{r}$ &, $667^{* *}$ & 1 \\
\cline { 2 - 4 } & $\mathrm{p}$ &, 000 & \\
\hline
\end{tabular}

Tablo 17 incelendiğinde, ölçeğin alt boyutları arasındaki korelasyon katsayısı .667 olup .05 düzeyinde anlamlı ilişkiye sahip olduğu görülmektedir. Açımlayıcı faktör analizi sonrasında ortaya çıkan modelin, yapı geçerliğini değerlendirmek için doğrulayıcı faktör analizi (DFA) yapılmıştır (Kline, 2011).

\section{Yüzyıl Yeterlilikleri Metaöğrenme Alt Ölçeği'nin Doğrulayıcı Faktör Analizi (DFA)}

21. Yüzyıl Yeterlilikleri Metaöğrenme Alt Ölçeğinin DFA sonucu elde edilen 2 faktörlü 16 madde içeren "Metaöğrenme Alt Ölçeği” doğrulayıcı faktör analizine tabi tutulmuştur. İlgili ölçeğin DFA sonuçları Tablo 18 'de verilmiştir. 
Tablo 18. 21. Yüzyıl Yeterliliklerinin Metaöğrenme Alt Ölçeği’nin DFA sonuçlarının uyum indeksi değerleri ve karşılaştırılması

\begin{tabular}{lllllll}
\hline Model & $\chi 2$ /sd & GFI & CFI & IFI & NNFI & RMSEA \\
\hline & $162,315 / 94=1,727$ &, 939 &, 968 &, 968 &, 928 &, 048 \\
\hline $\begin{array}{l}\text { Uyum } \\
\text { Yorumu* }\end{array}$ & Mükemmel Uyum & $\begin{array}{l}\text { Mükemmel } \\
\text { Uyum }\end{array}$ & $\begin{array}{l}\text { Mükemmel } \\
\text { Uyum }\end{array}$ & $\begin{array}{l}\text { Mükemmel } \\
\text { Uyum }\end{array}$ & $\begin{array}{l}\text { Mükemmel } \\
\text { Uyum }\end{array}$ & $\begin{array}{l}\text { Mükemmel } \\
\text { Uyum }\end{array}$ \\
\hline
\end{tabular}

*: (Bayram, 2013; Hu \& Bentler, 1999; Schumacker \& Lomax, 2004)

DFA sonucunda Ki kare değerinin serbestlik derecesine oranı, $(\chi 2 / \mathrm{sd}=1,727)$ ve GFI (Goodness of Fit Index), CFI (Comparative Fit Index), IFI (Incremental Fit Index) ve NNFI (Non-Normed Fit Index) uyum indeksleri ve RMSEA değeri ile iyi uyum gösterdiği anlaşılmıştır.

Ölçeğin her bir faktöründeki maddelerin bulunduğu faktörü temsil etme düzeyleri için standardize yol diyagramı Şekil 8'de gösterilmiştir.

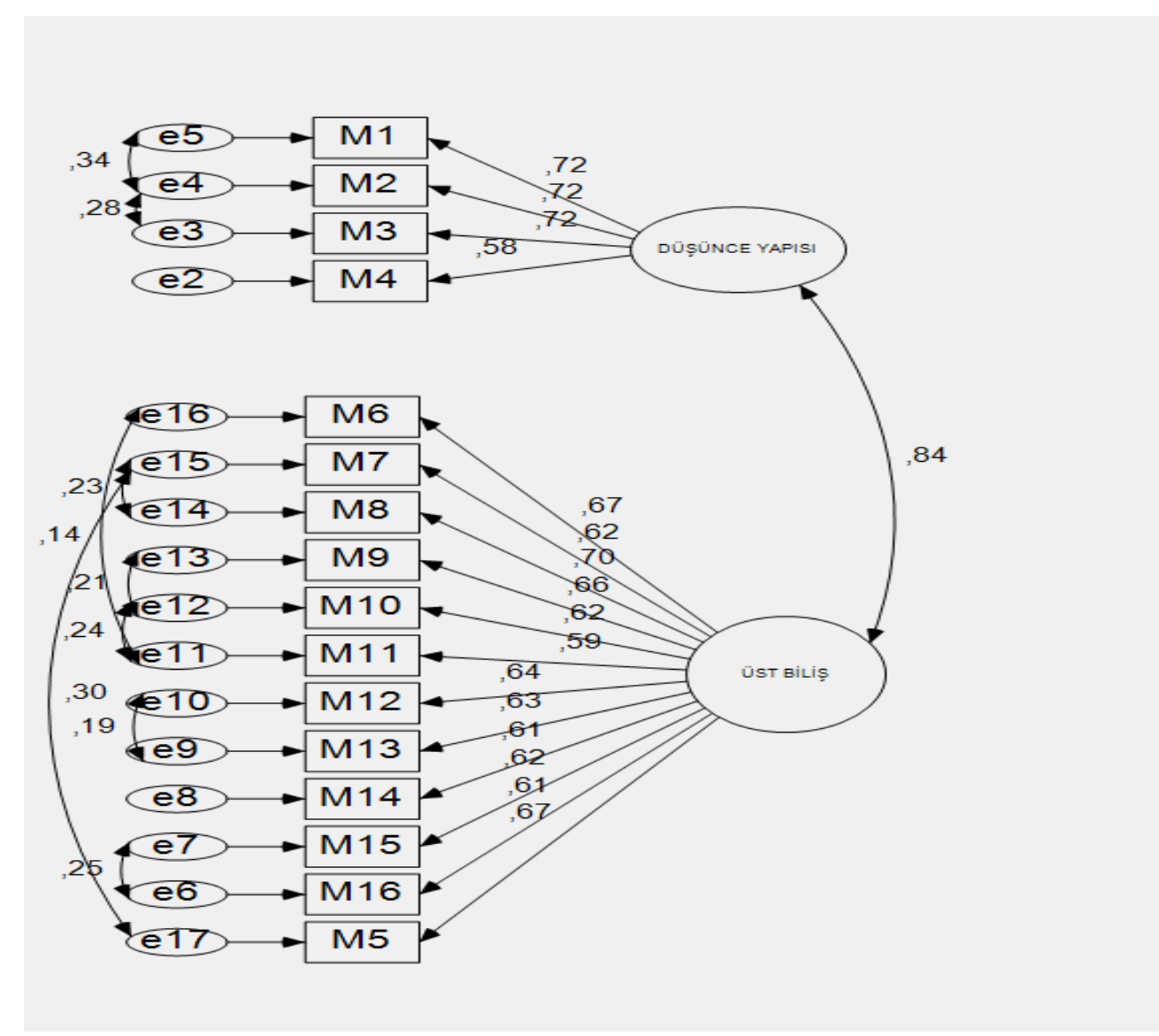

Şekil 8. 21. Yüzyıl Yeterlilikleri Metaöğrenme Alt Ölçeği’nin DFA Sonuçları: Standartlaştırılmış Yol Diyagramları

Maddelerin standardize yol katsayıları 0.58 ile 0.70 arasında değişmektedir. Bu değerler maddelerin bulundukları faktörleri iyi bir şekilde temsil ettiğini göstermektedir. 
Tablo 19. 21. Yüzyıl Yeterlilikleri Metaöğrenme Alt Ölçeği’nin maddelerine ait bazı geçerlik güvenirlik analizi değerleri

\begin{tabular}{|c|c|c|c|c|c|c|c|}
\hline Faktör & $\begin{array}{l}\text { Madde } \\
\text { No }\end{array}$ & $\begin{array}{l}\text { Madde- } \\
\text { toplam puan } \\
\text { korelasyonu }\end{array}$ & $\begin{array}{l}\text { AFA } \\
\text { faktör } \\
\text { yükü }\end{array}$ & $\begin{array}{l}\text { Alt üst } \\
\text { grup } \\
\text { farkı için } \\
\text { t değeri }\end{array}$ & $\begin{array}{l}\text { Madde } \\
\text { Ortalama }\end{array}$ & $\begin{array}{l}\text { Madde } \\
\text { Standart } \\
\text { sapma }\end{array}$ & $\begin{array}{l}\text { Cronbach } \\
\text { alfa } \\
\text { iç tutarlılık } \\
\text { katsayısı }\end{array}$ \\
\hline \multirow{4}{*}{$\begin{array}{l}\text { Düşünce } \\
\text { Yapısı }\end{array}$} & M1 &, 616 & ,766 & $14,59 * *$ & 4,39 &, 59 & \multirow{4}{*}{0.801} \\
\hline & M2 &, 631 &, 847 & $18,37 * *$ & 4,46 &, 53 & \\
\hline & M3 & ,613 &, 762 & $14,72 * *$ & 4,43 &, 56 & \\
\hline & M4 &, 501 &, 614 & $11,79 * *$ & 4,27 &, 67 & \\
\hline & M5 &, 641 & ,638 & $16,36^{* *}$ & 4,18 &, 68 & \multirow{12}{*}{0.895} \\
\hline & M6 &, 632 &, 580 & $15,21 * *$ & 4,32 &, 60 & \\
\hline & M7 & ,607 & ,691 & $15,93 * *$ & 4,21 & ,64 & \\
\hline & M8 &, 658 &, 728 & $17,02 * *$ & 4,23 &, 68 & \\
\hline & M9 &, 628 & ,669 & $15,00^{* *}$ & 4,20 &, 66 & \\
\hline & M10 & ,604 &, 657 & $16,66^{* *}$ & 4,37 &, 58 & \\
\hline \multirow{6}{*}{ Üstbiliş } & M11 &, 578 &, 544 & $15,32 * *$ & 4,40 &, 59 & \\
\hline & M12 &, 611 &, 588 & $11,94 * *$ & 4,33 &, 64 & \\
\hline & M13 &, 601 &, 635 & $13,35 * *$ & 4,27 &, 62 & \\
\hline & M14 &, 573 &, 598 & $13,60 * *$ & 4,22 &, 74 & \\
\hline & M15 &, 582 &, 647 & $14,10^{* *}$ & 4,38 &, 62 & \\
\hline & M16 &, 594 &, 576 & $14,33 * *$ & 4,38 & ,61 & \\
\hline
\end{tabular}

$$
* *: \mathbf{p}<.01
$$

21. Yüzyıl Yeterliliklerinin Metaöğrenme Alt Ölçeği’nin maddelerinin madde-toplam puan korelasyonu 0,573 ile 0,641 arasında değiştiği görülmektedir. Yine faktör yüklerinin 0,544üzerindedir. 21. Yüzy1l Yeterlilikleri Metaöğrenme Alt Ölçek maddelerinin üst ve alt grup madde puan ortalamaları arasında anlamlı bir farklılık olduğu görülmektedir. Metaöğrenme ölçeğin güvenirliğini belirlemek için Cronbach alfa iç tutarlılık katsayısına bakılmıştır. Yapılan güvenilirlik analizleri sonucunda tüm ölçeğin Cronbach alfa değeri 0.913 bulunmuştur. Ölçeğin faktörleri acısından bakıldığında birinci faktör olan düşünce yapısı için 0.801 ; ikinci faktör olan üstbiliş için 0.895 değerleri bulunmuştur.

21. Yüzyıl Yeterlilikleri Metaöğrenme Alt Ölçeği ile ilgili tüm verilere göre, ölçeğin güvenilir ve geçerli olduğu kabul edilmiştir.

Geliştirilen 21. Yüzyıl Yeterlilikleri Metaöğrenme Alt Ölçeği’nin boyutlarına dair puan değerlendirmelerini tablosu Tablo 20'de verilmiştir. 
Tablo 20. 21. Yüzyıl Yeterlilikleri Metaöğrenme Alt Ölçeği’nin puanlama tablosu

\begin{tabular}{|c|c|c|c|c|c|c|}
\hline \multirow{2}{*}{$\begin{array}{l}\text { 21. Yüzyıl Yeterlilikleri } \\
\text { Metaöğrenme Alt Ölçeğinin } \\
\text { Boyutları }\end{array}$} & \multirow[b]{2}{*}{ Maddeler } & \multicolumn{5}{|c|}{ Yeterlilik Düzeyi } \\
\hline & & $\begin{array}{l}\text { Çok } \\
\text { Düşük }\end{array}$ & Düşük & Orta & İyi & Çok İyi \\
\hline Düşünce Yapıs1 & $1,2,3$ ve 4 & $4-7,2$ & $\begin{array}{l}7,21- \\
10,4\end{array}$ & $\begin{array}{l}10,41- \\
13,6\end{array}$ & $\begin{array}{l}13,61- \\
16,8 \\
\end{array}$ & $\begin{array}{l}16,81- \\
20\end{array}$ \\
\hline Üstbiliş & $\begin{array}{l}5,6,7,8,9,10 \\
11 \\
12,13,14,15 \text { ve } \\
16\end{array}$ & $12-21,6$ & $\begin{array}{l}21,61- \\
31,2\end{array}$ & $\begin{array}{l}31,21- \\
40,8\end{array}$ & $\begin{array}{l}40,81- \\
50,4\end{array}$ & $\begin{array}{l}50,41- \\
60\end{array}$ \\
\hline Toplam & & $16-28,8$ & $\begin{array}{l}28,81- \\
41,6\end{array}$ & $\begin{array}{l}41,61- \\
54,4\end{array}$ & $\begin{array}{l}54,41- \\
67,2\end{array}$ & $\begin{array}{l}67,21- \\
80\end{array}$ \\
\hline
\end{tabular}

21. Yüzyıl Yeterlilikleri Metaöğrenme Alt Ölçeği, alt boyutlarıyla ve toplam bir şekilde puanlamaktadır. Ters puanlama gerektiren madde yoktur. Alınan yüksek puan kişinin ilgili boyutta yeterliliğe yüksek düzeyde sahip olduğu, düşük puan ise ilgili alanda yeterliliğe düşük düzeyde sahip olduğunu göstermektedir.

\section{Tartışma ve Sonuç}

21. Yüzyıl yeterliliklerini ölçmek amacıyla geliştirilen ölçeğin geçerli ve güvenilir olduğu bulunmuştur. Ölçek en son hali ile 80 maddeden oluşmaktadır. 21. Yüzyıl Yeterlilik Ölçeği; Bilgi, Beceri, Karakter ve Metaöğrenme isimli 4 alt ölçekten oluşmaktadır. Her bir alt ölçek diğer ölçeklerden bağımsız bir şekilde kullanılabilmektedir. 21. yüzyıl yeterlilik ölçeğin tüm alt ölçeklerinin doğrulayıcı faktör analizinin uyum belirteçleri ile belirlenmiş ve bu model kuramsal olarak ve istatiksel açıdan uygun bulunmuştur.

21. Yüzyıl Yeterlilik Ölçeğinin Bilgi alt ölçeği, 27 maddeden oluşmaktadır. Bilgi alt ölçeğinin yedi alt boyutu vardır. Bunlar; Girişimcilik, Kişisel Finans, Sosyal Sistem, Teknoloji-Mühendislik, Biyoenerji, Medya ve Sağlık boyutlarıdır. Bilgi alt ölçeğinin boyutlarının güvenirlik katsayıları, 0.62 ile 0.84 arasında değişmektedir.

21. Yüzyıl Yeterlilik Ölçeğinin Beceri alt ölçeği 18 maddeden oluşmaktadır. Ölçek dört alt boyuttan oluşmaktadır. Bunlar; İletişim, Eleştirel Düşünme, Yaratıcılık ve İşbirliği Öğrenme alt boyutlarıdır. Beceri alt ölçeğinin boyutlarının güvenirlik katsayıları, 0.61 ile 0.83 arasında değişmektedir.

21. Yüzyıl Yeterlilik Ölçeğinin Karakter alt ölçeğinde 19 madde vardır. Bu maddeler dört alt boyutta kümelenmiştir. Kümelenme sonucunda ortaya çıkan alt boyutlar; Liderlik, Ahlak, Merak ve Farkındalık’tır. Karakter alt ölçeğinin boyutlarının güvenirlik katsayıları, 0.64 ile 0.84 arasında değişmektedir.

21. Yüzyıl Yeterlilik Ölçeğinin Metaöğrenme alt ölçeği, 16 maddeyi kapsamaktadır. Bu maddeler iki alt boyuta dağılmıştır. Bu boyutlardan birisi, Düşünce Yapısı diğgeri ise Üstbiliş’tir. Karakter alt ölçeğinin Düşünce Yapısı boyutunun 0,80; diğer alt boyutu olan Üstbiliş'in 0,89'tur.

Ölçek alt boyutlarıyla ve toplam bir şekilde puanlamaktadır. Ters puanlama gerektiren madde yoktur. Her bir alt boyutla ilgili maddeler verilen cevaplara göre toplanmakta ve ölçeğin ilgili alt boyutunun puanı hesaplanmaktadır. Ölçekten toplam puan elde edilirken tüm maddelerden alınan puanlar toplanmaktadır. Alınan yüksek puan kişinin ilgili boyutta yeterliliğe yüksek düzeyde sahip olduğu, düşük puan ise ilgili alanda yeterliliğe düşük düzeyde sahip olduğunu göstermektedir.

Sonuç olarak; üniversite öğrencilerine yönelik olarak geliştirilen 21. Yüzyıl Yeterlilik Ölçeğinin geçerlik ve güvenirlik ölçeğin yeterli düzeyde psikometrik özelliklere sahip olduğunu göstermiştir. Bu sonuçlara bakılarak ölçeğin üniversite öğrencilerinin 21. yüzyıl yeterliklerinin ölçülmesinde kullanılabileceği ve gerekli dönütleri sağlamada yeterli olacağı söylenebilir. 


\section{Kaynakça}

Akpınar, Y. ve Altun, A (2014). Bilgi toplumu okullarinda programlama eğitimi gereksinimi. Elementary Education Online, 13(1), 1-4.

Aksoy, G. (2006). İşbirlikçi Öğrenme yönteminin genel kimya lâboratuvari dersinde akademik başariya, lâboratuvar malzemesi tanima ve kullanma becerisine etkisi. Yükseklisans Lisans Tezi. Erzurum: Atatürk Üniversitesi / Fen Bilimleri Enstitüsü/ İlköğretim Anabilim Dalı.

Altunbay, M. (2015). Illköğretim Türkçe Dersi (6-7-8. Sinıflar) öğretim programinda yer alan temel becerilerin kazandirilmasinda çocuk edebiyati ürünlerinin etkisi (21. yüzyil örneklemi). Doktora Tezi. Ankara: Gazi Üniversitesi / Eğitim Bilimleri Enstitüsü/ Türkçe Eğitimi Anabilim Dalı.

Arslan, N. ve Durukan, E. (2015). Türkiye ortaokul öğrencilerinin öğrenme stilleri ve yazma eğilimleri arasindaki ilişki. Uluslararası Türkçe Edebiyat Kültür Eğitim Dergisi, 4(3), 1251-1267.

Aybek, B., Aslan, S., Dinçer, S. ve Coşkun-Arısoy, B. (2015). Öğretmen adaylarina yönelik eleştirel düşünme standartlari ölçeği: geçerlik ve güvenirlik çalişması. Kuram ve Uygulamada Eğitim Yönetimi, 21(1), 2550. doi: $10.14527 /$ kuey.2015.002

Barmaki, N. (2015). Öğrencilerinin Finansal okuryazarlik düzeylerini belirlemeye yönelik bir araștirma: Hacettepe Üniversitesi örneği. Doktora Tezi. Ankara: Hacettepe Üniversitesi/ Sosyal Bilimler Enstitüsü/ Aile ve Tüketici Bilimleri.

Baş, K. (2012). Sosyal Bilgiler Dersinde İşbirlikçi Öğrenme Yönteminin Yedinci Sinıf Öğrenci Başarısına Olan Etkisi. Yükseklisans Lisans Tezi. Kilis: Kilis 7 Aralık Üniversitesi/ Sosyal Bilimler Enstitüsü/ İlköğretim Anabilim Dalı.

Bayram, N. (2013). Yapısal eşitlik modellemesine giriş AMOS Uygulamaları. Bursa: Ezgi Kitabevi.

Biçer, O. (2008). Yabancı dil eğitiminde öğrenci motivasyonu, fransizca eğitiminde öğrenci motivasyonunun başariya etkileri. Yüksek Lisans Tezi. Ankara: Gazi Üniversitesi/ Eğitim Bilimleri Enstitüsü/ Fransızca Öğretmenliği Anabilim Dalı.

Bozkurt, A. (2014). Ağ toplumu ve bilgi. Türk Kütüphaneciliği, 28 (4), 510-525.

Boztepe, Ö. (2017). Öğretmen adaylarinin yaşam boyu öğrenme ve iletişim memnuniyet düzeylerinin incelenmesi. Yüksek Lisans Tezi. Sakarya: Sakarya Üniversitesi/ Eğitim Bilimleri Enstitüsü/ Eğitim Bilimleri Anabilim Dalı.

Büyüköztürk, Ş. (2015). Sosyal bilimler için veri analizi el kitabi. (21. Baskı). Ankara: Pegem Yayınları.

Cabı, E. (2016). Attitude Scale for digital technology, (dijital teknolojiye yönelik tutum ölçeği). Kastamonu Ĕ̆itim Dergisi, 24 /3, 1229-1244.

Çolak, M. (2018). Ortaokul fen bilimleri dersinin 21.yüzyil becerilerini kazandirmadaki etkililiğine ilişkin ögretmen görüssleri (Kayseri ili örneği). Yüksek Lisans Tezi. Kayseri: Erciyes Üniversitesi/ Eğitim Bilimleri Enstitüsü/ Eğitim Bilimleri Anabilim Dalı.

Doğan, A. (2013). Üstbiliş ve üstbilişe dayali öğretim. Middle Eastern and African Journal of Educational Research, 3, 6-20.

Doğan, N., Soysal, S. ve Karaman H. (2017). Ayni örnekleme açimlayici ve doğrulayici faktör analizi uygulanabilir mi?. küreselleşen dünyada eğitim. (Demirel, Ö. ve Dinçer, S., Ed.) Ankara: Pegem Akademik Yayıncılık Eğitim Danışmanlık Tic. Ltd. Şti.

Dönmez, B. ve Kaya, F. (2016). Eleștirel düşünme motivasyonu ölçeği’nin türkçe'ye uyarlanmasi. Hasan Ali Yücel Eğitim Fakültesi Dergisi, 13-2 (25), 159-173.

Ekici, G., Abide, Ö. F., Canbolat, Y. ve Öztürk, A. (2017). 21.Yüzyil becerilerine ait veri kaynaklarinin analizi. Journal of Research in Education and Teaching. Ĕgitim ve Öğretim Araştırmaları Dergisi, 6(1), 1-12. ISSN: 2146-9199

Ekinci, N. (2015). Öğretmen adaylarinin öğrenme yaklaşimlari ve öğretmen özyeterlik inançlari arasindaki ilişki. Hacettepe Üniversitesi Eğitim Fakültesi Dergisi (H. U. Journal of Education), 30(1), 62-76.

Ersanl1, K. ve Balcı, S. (1998). İletişim becerileri envanterinin geliştirilmesi: Geçerlik ve güvenirlik çalişmasi. Türk Psikolojik Duruşma ve Rehberlik Dergisi, 2(10), 7-12. 
Eryılmaz, S. ve Uluyol, Ç. (2015). Evaluation of FATIH project in the consideration of 21st century skills. 21. yüzyil becerileri işiğinda FATIH projesi değerlendirmesi. GEFAD / GUJGEF, 35(2), 209-229.

Gay, L. R., Mills, G. E., \& Airasian, P. W. (2009). Educational research: competencies for analysis and applications, student value edition. Upper Saddle River, NJ: Merrill. (Hu \& Bentler, 1999).

Gelen, İ. (2017). P21-Program ve öğretimde 21. yüzyil beceri çerçeveleri (abd uygulamalari). Journal of Interdisciplinary Educational Research. Disiplinlerarası Eğitim Araştırmaları Dergisi, 1(2), 15-29.

Göksun, D. O. Ve Kurt, A. A. (2017). Öğretmen adaylarinin 21. yy. öğrenen becerileri kullanimlari ve 21. yy. öğreten becerileri kullanimlari arasindaki ilişki. Eğitim ve Bilim Dergisi, 42(190), 107-130. DOI: 10.15390/EB.2017.7089

Göncüoğlu, Ö. G. (2010). 6. sinif sosyal bilgiler dersi demokrasinin, serüveni ünitesinin ögretimde drama ve işbirlikçi ögretim yöntemlerinin ögrenci tutum ve başarisina etkisi. Yüksek Lisans Tezi. Niğde: Niğde Üniversitesi/ Sosyal Bilimler Enstitüsü/ İlköğretim Anabilim Dalı.

Gülay, G. (2013). Emeklilik Planlama Süreci Ölçeğinin Türkçe geçerlilik ve güvenirlik çalişmasi: Karabük Üniversitesi örneği. Turkish Journal of Geriatrics, 16 (1), 84-94.

Güneş, A. (2017). 21. Yüzyll vatandaşliğinin geliştirilmesinde açik ve uzaktan öğrenme: bir metafor analizi araştirmasi. Yüksek Lisans Tezi. Eskişehir: Anadolu Üniversitesi/ Sosyal Bilimler Enstitüsü/ Uzaktan Eğitim Anabilim Dalı.

Günüç, S., Odabaşı, H. F. ve Kuzu, A. (2013). The defining characteristics of students of the 21st century by student teachers: a twitter activity. 21. yüzyil öğrenci özelliklerinin öğretmen adaylari tarafindan tanimlanmasi: bir twitter uygulaması. Eğitimde Kuram ve Uygulama, Journal of Theory and Practice in Education, 9(4), 436-455. ISSN: 1304-9496

Güven, M. ve Kürüm, D. (2006). Öğrenme stilleri ve eleştirel düşünme arasindaki ilişkiye genel bir bakiş. Sosyal Bilimler Dergisi, 1, 75-90.

Hu, L. ve Bentler, P. M. (1999). Cutoff criteria for fit indexes in covariance structure analysis: conventional criteria versus new alternatives. Structural Equation Modeling, 6(1), 1-55.

Kalayc1, Ş. (2014). SPSS uygulamali çok değişkenli istatistik teknikleri (6.Baskı). Ankara: Asil.

Kasalak, İ. (2017). Robotik kodlama etkinliklerinin ortaokul ögrencilerinin kodlamaya ilişkin öz-yeterlik algilarina etkisi ve etkinliklere ilişkin öğrenci yaşantilari. yüksek lisans tezi. ankara: Hacettepe Üniversitesi/ Eğitim Bilimleri Enstitüsü/ Bilgisayar ve Öğretim Teknolojileri Eğitimi Anabilim Dalı.

Kenar, İ. (2012). Teknoloji ve derslerde teknoloji kullanimina yönelik veli tutum ölçeği geliştirilmesi ve tablet pc uygulamasi. Eğitim Bilimleri Araştırmaları Dergisi, Journal of Educational Sciences Research, 2, 123 139.

Kılıç, R. ve Kurtuluş, A. (2009). Webquest destekli işbirlikçi öğrenme yönteminin matematik dersindeki tutum ve erişiye etkisi. e-Journal of New World Sciences Academy Education Sciences, 4 (1), 62-70. 1 C0006

Kline, P. (1994). an easy guide to factor analysis. NY: Routledge.

Kline, R. B. (2011). Principles and practice of structural equation modeling. New York: Guilford Publications.

Korkut Owen, F. ve Bugay, A. (2014). İletişim becerileri ölçeği’nin geliştirilmesi: geçerlik ve güvenirlik çalişmasi. Mersin Üniversitesi Eğitim Fakültesi Dergisi, 10(2), 51- 64.

Korkut, E. ve Akkoyunlu B. (2008). yabanci dil öğretmen adaylarinin bilgi ve bilgisayar okuryazarlik özyeterlikleri. H. U. Journal of Education (Hacettepe Üniversitesi Eğitim Fakültesi Dergisi ), 34, 178-188.

Korkut, F. (1996). İletişim becerilerini değerlendirme ölçeğinin geliştirilmesi: Güvenirlik ve geçerlik çalişmaları. Psikolojik Danışma ve Rehberlik Dergisi, 2(7), 18-23.

Kuhlthau, C. C., Maniotes, L. K. \& Caspari, A. K. (2015). Guided Inquiry: Learning in the 21st Century: Learning in the 21 st Century. ABC-CLIO.

Ledward, B. C., \& Hirata, D. (2011). An Overview of 21 st century skills. honolulu: kamehameha schools research \& evaluation 04.15.2018 tarihinde http://www.ksbe.edu/_assets/spi/pdfs/21st_Century_Skills_Brief.pdf adresinden alınd. 
Narin, N. (2009). Illköğretim İkinci Kademe Sosyal Bilgiler Öğretmenlerinin Eleştirel düşünme becerilerinin incelenmesi. Yüksek Lisans Tezi. Adana: Çukurova Üniversitesi/ Sosyal Bilimler Enstitüsü/ Eğitim Bilimleri Anabilim Dalı.

Özsoy, G. (2008). Üstbiliş. Türk egitim bilimleri dergisi, 6(4), 713-740.

Pamukcu, B. S. (2013). Bilgisayar ve öğretim teknolojileri ĕgitimi anabilim dali işbirlikçi öğrenmeyi destekleyen üç-boyutlu çevrimiçi öğrenme ortami geliştirilmesi ve kullanilabilirliğinin değerlendirilmesi. Yüksek Lisans Tezi. Ankara: Gazi Üniversitesi/ Eğitim Bilimleri Enstitüsü/ Bilgisayar ve Öğretim Teknolojileri Eğitimi Anabilim Dalı.

Pett, M. A., Lackey, N. R., \& Sullivan, J. J. (2003). Making sense of factor analysis. the use of factor analysis for instrument development in health care research. Thousand Oaks, CA: Sage Publications

Sarıgöz, O. (2014). Öğretmen adaylarinin eleştirel düşünme becerileri hakkindaki görüşlerinin değerlendirilmesi. Akademik Bakış Dergisi, Uluslararası Hakemli Sosyal Bilimler E-Dergisi, 41. ISSN:1694-528X

Savaş E. (2011). Illköğretim Okulu sekizinci sinif öğrencilerinin bilimsel bilginin tanimi ve özellikleri hakkindaki bilgileri. Yüksek Lisans Tezi. Ankara: Hacettepe Üniversitesi/ Sosyal Bilimler Enstitüsü/ Eğitim Bilimleri Anabilim Dalı.

Şahin, M. C. (2010). Eğitim fakültesi öğrencilerinin yeni binyilin öğrencileri. (oecd-new millennium learners) ölçütlerine göre dĕgerlendirilmesi. Doktora Tezi. Eskişehir: Anadolu Üniversitesi/ Eğitim Bilimler Enstitüsü/ Bilgisayar ve Öğretim Teknolojileri Eğitimi Anabilim Dalı.

Schumacker, R. E., \& Lomax, R. G. (2004). A Beginner's guide to structural equation modeling (2nd ed.). Mahwah, NJ, US: Lawrence Erlbaum Associates Publishers.

Seferoglu, S. S ve Akbıyık C. (2006). Eleştirel düşünme ve ögretimi. H.Ü. Eğitim Fakültesi Dergisi (H.U. Journal of Education), 30, 193-200.

Şeker, H ve Gençdoğan, B. (2014). Psikolojide ve eğitimde ölçme araci geliştirme. (2. Basım). Ankara: Nobel Yayınevi.

Şen, Ü. (2009). An Evaluatıon About Turkısh Teacher Candıdates' Crıtıcal Thınkıng Attıtude's In Terms Of Dıfference Varıable (Türkçe Öğretmeni Adaylarının Eleştirel Düşünme Tutumlarının Çeşitli Değişkenler Açısından Değerlendirilmesi). Zeitschrift für die Welt der Türken Journal of World of Turks, 1(2), 69-89.

Sungur, O. (2011). İşletme kuluçkalari destek hizmetlerinin firma hayatta kalma üzerindeki rolü: cox orantili hazard regresyon modeli ile iş geliştirme merkezlerine (işgem) yönelik ampirik bir analiz. Doktora Tezi. Isparta: Süleyman Demirel Üniversitesi/ Sosyal Bilimleri Enstitüsü/ İktisat Anabilim Dalı.

Tavşancıl, E. (2005). Tutumların ölçülmesi ve spss ile veri analizi. Ankara: Nobel Yayıncılık.

Tekin Bender, M. (2006). Resim-iş eğitimi ögrencilerinde duygusal zeka ve yaraticilik ilişkileri. Doktora Tezi. İzmir: Dokuz Eylül Üniversitesi/ Eğitim Bilimleri Enstitüsü/ Güzel Sanatlar Eğitimi Anabilim Dalı.

Tosun, A. E. (2016). Öğrencilerinin finansal okuryazarlik düzeyi üzerine bir alan araştirması. Yüksek Lisans Tezi. Trabzon: Karadeniz Teknik Üniversitesi/ Sosyal Bilimleri Enstitüsü/ İşletme Anabilim Dalı.

Ünlü, M. (2008). Işsbirlikçi ögrretim yönteminin 8. sinif öğrencilerinin matematik dersi "permütasyon ve olasilik”" konusunda akademik başari ve kalicilik düzeylerine etkisi. Yüksek Lisans Tezi. Ankara: Gazi Üniversitesi/ Eğitim Bilimleri Enstitüsü/ İlköğretim Anabilim Dalı.

World Economic Forum- WEF, (2016). drivers of change. (n.d.).retrieved january 10,2017, from https://reports.weforum.org/future-of-jobs-2016/drivers-of-change/ Yaratıcı düşünme. 21 Mart 2017 tarihinde https://tr.wikipedia.org/wiki/Yaratıcı_Düşünme adresinden alındı.

Yalçın, S. (2018). 21. yüzyil becerileri ve bu becerilerin ölçülmesinde kullanilan araçlar ve yaklaşimlar. Ankara Üniversitesi Ë̆itim Bilimleri Fakültesi Dergisi, 51 (1), 183-201. DOI:10.30964/auebfd.405860, E-ISSN: 2458-8342, P-ISSN: 1301-8342

Yanık, S. (2007). İş Geliştirme ve iş modelleri: dünya uygulamaları. Yüksek Lisans Tezi. İstanbul: İstanbul Teknik Üniversitesi/ Fen Bilimleri Enstitüsü/ Endüstri Mühendisliği Anabilim Dalı.

Yıldırım, B. ve Selvi, M. (2015). Adaptation of stem attitude scale to turkish . Turkish Studies International Periodical For The Languages, Literature and History of Turkish or Turkic Volume, 10(3), 1117-1130. DOI Number: http://dx.doi.org/10.7827/TurkishStudies.7974 ISSN: 1308-2140 
Yılmaz, E. ve Sünbül, A. M. (2009). Üniversite öğrencilerine yönelik girişimcilik ölçeğinin geliştirilmesi. Selçuk Üniversitesi Sosyal Bilimler Enstitüsü Dergisi, 21, 195-203.

Yılmaz, E., Çalışkan, M., ve Sulak, S. A. (2016). Eğitim bilimlerinden yansimalar. Konya: Çizgi Kitabevi Yayınları. ISBN: 978-605-9427-19-7

Yüksel, H. (2014). İnternet gazeteciliğinde bilgi kirliliği Sorunu. Atatürk İletişim Dergisi, 6, 124-134.

\section{Extended Abstract}

The aim of this research is to develop a valid and reliable measurement tool to measure the 21 st Century Qualifications of university students and older.

University students are required to practice these skills in every aspect of their lives and to use them. For this reason, it is important to determine the extent to which university students possess these skills. The aim of this study is to develop a valid and reliable measurement tool called "21st Century Competencies Scale" which can measure the degree to which university students have these qualifications.

This study was carried out by following the steps of scale development process. In the scale development process, firstly the related literature was reviewed and a scope was formed. Within this scope, item pool was created. The items in the item pool were presented to the opinion of 15 experts and a pre-trial form was created by reducing the scale of 110 items to 89 items and revising the items within the scope of the feedback received.

21st Century Proficiency Scale; It consists of 4 subscales: Knowledge, Skills, Character and Metalearning.Each subscale is structured so that it can be used independently of the other scales. The pre-trial form of this structured scale was applied to 560 university students to determine the construct validity of the scale.

Each subscale was subjected to exploratory and confirmatory factor analysis independently of the other scales. As a result of the analyzes, items related to the Knowledge subscale of the 21st Century Qualification Scale were collected under seven factors (Entrepreneurship, Personal Finance, Social System, Technology-Engineering, Bioenergy, Media and Health). The items related to the Skill subscale of the 21 st Century Proficiency Scale were grouped under four factors (Communication, Critical Thinking, Creativity and Cooperative Learning).

The items related to the Character subscale of the 21st Century Proficiency Scale were grouped under four factors (Leadership, Ethics, Curiosity and Awareness). The items related to the MetaLearning subscale of the 21 st Century Proficiency Scale were collected under two factors (Thought Structure and Metacognition). The models determined with the fit markers of the confirmatory factor analysis in which the items related to all subscales were found to be theoretically and statistically appropriate. As a result, it was shown that the scales developed to measure the 21st Century Qualifications of university students and over are valid and reliable and have sufficient psychometric properties.

Key Words: 21 st Century qualifications, Knowledge, Skill, Character, MetaLearning, Scale Development. 